\title{
Preliminary analysis on roles of metal-organic compounds in the formation of invisible gold
}

\author{
Medet Junussov $^{1}$ (D) Mádai Ferenc $^{2} \cdot$ Kristály Ferenc $^{1} \cdot$ Tóth Tivadar $^{3} \cdot$ \\ Fintor Krisztián ${ }^{3} \cdot$ Muránszky Gábor $^{4} \cdot$ Prekob Ádám $^{4} \cdot$ Hámor-Vidó Mária ${ }^{5}$
}

Received: 25 January 2021/Revised: 12 August 2021/Accepted: 16 August 2021/Published online: 9 September 2021

(C) The Author(s) 2021

\begin{abstract}
The paper comprises new analytical data on the nature and occurrence of gold in solid pyrobitumen, closely associated with the main gold-bearing sulfide arsenic ores of the Bakyrchik gold deposit (Kazakhstan), related to post-collisional magmatic-hydrothermal origin. Gold mineralization of the deposit occurs mainly in the form of an "invisible" type of gold in the structures of arsenian pyrite and arsenopyrite, and the form of gold-organic compounds of pyrobitumen in carbonaceous-terrigenous sequences of Carboniferous formation. Microscopic and electron microscopic analysis, Raman and FT-Infrared analysis, mineralogical and three-step sequential extraction analysis $\left(\mathrm{NH}_{2} \mathrm{OH} \cdot \mathrm{HCl}, \mathrm{H}_{2} \mathrm{O}_{2}, \mathrm{HNO}_{3}+\mathrm{HCl}\right)$ has been carried out using 9 ore samples (from 3 different types of ores) for a comprehensive study of pyrobitumen and sulfide arsenic ores focusing mainly on organic matter. The sequentially extracted precious metal content of pyrobitumen reaches
\end{abstract}

up to $7 \mathrm{ppm}$ gold and other metals like $\mathrm{Ag} 4 \mathrm{ppm}$, Pt $31 \mathrm{ppb}$, and $\mathrm{Pd} 26 \mathrm{ppb}$, forming metal-organic compounds, while arsenic sulfide minerals incorporate $11 \mathrm{ppm}$ gold, $39 \mathrm{ppm} \mathrm{Ag,} 0.49 \mathrm{ppm}$ Pt. The enrichment of gold associating with organic matter and sulfide ore minerals was confirmed in this study. Organic matter was active in the migration of gold and the capture of gold by pyrobitumen. Moreover, the reductive organic matter agent released gold, most likely for the sulfide arsenic ore minerals. Pyrobitumen was a decisive factor in the concentration, transportation, and preservation of gold in the deposit.

Keywords Gold · Pyrobitumen · Bakyrchik · Vitrinite . Metal-organic compounds

1 Department of Mineralogy and Petrography, Institute of Mineralogy and Geology, Faculty of Earth Sciences and Engineering, University of Miskolc, Miskolc-Egyetemváros 3515, Hungary

2 Institute of Mineralogy and Geology, Faculty of Earth Sciences and Engineering, University of Miskolc, Miskolc-Egyetemváros 3515, Hungary

3 Department of Mineralogy and Geochemistry, Faculty of Science and Informatics, University of Szeged, Aradi vértanúk tere 1, Szeged 6720, Hungary

4 Institute of Chemistry, Faculty of Material Sciences and Engineering, University of Miskolc, Miskolc-Egyetemváros 3515, Hungary

5 Department of Geology and Meteorology, Institute of Geography and Earth Sciences, Faculty of Sciences, University of Pécs, Vasvári pál utca, Pecs 7622, Hungary 


\section{Introduction}

Analytical and experimental analysis of metal-organic compounds of solid pyrobitumen is the main aim of the study in this paper. The study of solid pyrobitumen and its relationship with the "invisible" gold leads to three research tasks: to determine the occurrence and mechanism of migration and entrapment of gold by liquid hydrocarbons (1); the preservation of gold in hydrothermally altered sedimentary rocks (2); and to understand the impact of hydrocarbon migration on gold mineralization resulting in the formation of "invisible gold" in arsenic sulfide minerals (3).

The so-called type "invisible gold" as first described by Bürg (1930), is ionic gold (or submicroscopic form) in the form of a solid solution structurally binding in arsenic sulfides (Cabri et al. 1989; Cook and Chryssoulis 1990; Fuxin et al. 2001; Vikent'ev 2006; Wu et al. 2016; Volkov et al. 2017; Osovetsky 2017; Large and Maslennikov 2020), which is not detectable by electron microscopy, being smaller than $0.1 \mu \mathrm{m}$ (up to $10 \mathrm{~nm}$ ) with concentration less than 0.5 ppm (Cook and Chryssoulis 1990; Large and Maslennikov 2020) It accounts for 10\%-15\% of world gold production (Berger 2014). Gold content generally increases with arsenic content (Fleet et al. 1993), possibly related to arsenic content in the host mineral (Cabri et al. 1989) which is common in arsenopyrite (Cook and Chryssoulis 1990), since gold can substitute $\mathrm{Fe}$ in the arsenopyrite lattice (Wu and Delbove 1989). Gold-rich arsenopyrite is paragenetically associates with organic materials (Hanping et al., 1999). Therefore, organic materials are often found in sulfide deposits with invisible gold sulfide deposits (Jiuling et al. 1997), where there is a positive correlation between gold content and organic carbon (Farel' 1980,1984), being an active chemical agent in ore-forming processes (Giordano 1994; Giordano and Kharaka 1994). It was assumed that gold sulfide ores and organic materials are deposited together as a result of precipitation caused by changes in temperature, pressure, and $\mathrm{pH}$ of the gold-bearing fluid (Romberger 1988) with the formation of metal-organic compounds, where organic matter can play a significant role in the metallogenesis of a sulfide gold deposit (Gatellier and Disnar 1989; Parnell and McCready 2000; Ross et al. 2011).

The formation of metal-organic compounds has been investigated by many authors (Merwin 1968; Radtke and Scheiner 1970; Baskakova 1970; Saxby 1976; Emsbo and Koenig 2007; Parnell and McCready 2000; Ross et al. 2011; Migdisov et al. 2017) in coal, bitumen and solid pyrobitumens in which gold occurs in soluble and insoluble fractions from a few tenths of ppb to several thousands of ppm (Crocket 1991; Wood 1996; Razvozzhaeva et al.
2002; Ross et al. 2011; Fuchs et al. 2016). The role of metal-organic compounds in migration and entrapment of gold has been reported by several authors (Baskakova 1970; Saxby 1976; Boyle 1979; Giordano 2000; Migdisov et al. 2017; Simoneit 2000, 2018). The organic matter of phenolic aromatic and thiophenic sulfur compounds in hot aqueous ore fluids can favor the transfer of metals (Giordano and Kharaka 1994; Giordano 2000) and accumulation with metals occurred in the transformation from liquid bitumen, later precipitated as solid bitumen and, finally into solid pyrobitumen.

Solid pyrobitumen, as defined by Stasiuk (1997), is a high-temperature form of solid bitumen (Jacob 1989), a highly aromatic and insoluble bituminous substance (Glikson et al. 2000; Huc et al. 2000) of higher rank (more than $\mathrm{R}_{0}=2 \%$ ). It has no fluorescence or weak (brown, wavelength $>650 \mathrm{~nm}$ ) fluorescence (Glikson et. al. 2000) and occurs as petroleum (Rogers et al. 1974; Milner et al. 1977; Hunt 1978; Jacob 1985), as direct thermal cracking of oil at great burial depths (Waples 2002), where it is generally related to magmatic activity and hydrothermal fluid convection at temperatures from 60 to $400{ }^{\circ} \mathrm{C}$ ( $\mathrm{Si}$ moneit 1994, 2000, 2018).

\section{Geological settings}

\subsection{The deposit and regional geology}

The sulfide-ore-bearing carbonaceous-sedimentary formation of the Bakyrchik gold deposit is located in Auezov township (75 km from Óskemen city), East Kazakhstan. The gold reserves of the deposit are $410 \mathrm{t}$, on average 8-9 g/t (Goldfarb et al. 2014; Dyachkov et al. 2017). Gold mineralization is of a stratiform type (Zhautikov and Maulenov 1985) formed in the Middle-Late Carboniferous $\left(\mathrm{C}_{2-3}\right)$ (Dyachkov et al. 2011). The bulk $(90 \%)$ of gold in the deposit occurs as an "invisible gold" type, bound to the lattice of arsenian pyrite and arsenopyrite (Umarbekova and Dyusembaeva 2019) and gold concentrates in a structure of amorphous organic matter (Marchenko and Komashko 2011). Gold is enriched with arsenic sulfide minerals in the presence of organic matter $(0.2 \%-0.4 \%)$ in host siltstone rocks (Rafaylovish et al. 2011; Azerbaev and Zhautikov 2013). The presence of gold in the carbonaceous matter has a sedimentogenic origin in association with other precious metals (Azerbaev and Zhautikov 2013).

The total carbon content of the organic carbon and carbonates is $0.3 \%-26.5 \%$ in the host rocks and $2.5 \%-6 \%$ in ore zones (Rafaylovich et al. 2011). In ore zones, the content of arsenopyrite ranges from $0.3 \%$ to $15 \%$ while arsenian pyrite varies between $1.5 \%$ and $22 \%$ (Rafaylovich et al. 2011). The gold content in organic matter can reach 
$10 \%-30 \%$ in the form of a metal-organic complex (Marchenko 2010), while the gold content in arsenopyrite can reach more than 150 and $60 \mathrm{ppm}$ in arsenian pyrite (Levitan 2008), respectively. Platinum group metals are also common in arsenian pyrite and arsenopyrite-bearing ores, up to $1 \mathrm{ppm}$ (Rafaylovich et al. 2011), forming nanoand microforms (Narseev et al. 2001), and in nanostructured particles of organic materials in the deposit (Marchenko and Komashko 2011).

The regional geology of the Bakyrchik gold deposit, as explained by Lubecky (2008) and (Wong 2017) shows that the gold deposit was formed in an ophiolite suture zone relating to post-tectonic plate collisions of the Kazakhstan microcontinent and the Siberian craton in the Late Carboniferous $\left(\mathrm{C}_{3}\right)$, which includes the Late Palaeozoic Variscan Orogenic tectono-magmatic event (Parnell 2019).

Parnell (2019) considered the deposit as one of the most important gold occurrences related to the global coal reservoir of Variscan gold formation during the Late Carboniferous (300 Ma). During the tectono-magmatic event, the collision contributed to the formation of the Kunush granitic batholith in the Late Carboniferous-Early Permian $\left(\mathrm{C}_{3}-\mathrm{P}_{1}\right)$ (Rafaylovich 2009) and the Qyzyl thrust fault (Dyachkov et al. 2017). The Qyzyl thrust fault (2 km long and $30^{\circ}-50^{\circ}$ dip in the north) lies within the ore bodies, occurs in carbonaceous-terrigenous rocks of molasses and limnic coal-bearing formations of the Middle-Late Carboniferous $\left(\mathrm{C}_{2-3}\right)$ Bukon suite in the Middle-Late Carboniferous $\left(\mathrm{C}_{2-3}\right)$ (Dyachkov et al. 2011; Umarbekova et al. 2017b), as shown in Fig. 1a, b.

\subsection{Stratigraphy}

The recent structure of the deposit shows to a terrigenous basin, including a carboniferous sequence from the marine in the Early Carboniferous $\left(\mathrm{C}_{1}\right)$, coastal-marine in the Middle Carboniferous $\left(\mathrm{C}_{2}\right)$, and continental carbonaceous molasses in the Middle-Late Carboniferous $\left(\mathrm{C}_{2-3}\right)$ (Lubecky et al. 2008), see Fig. 1b. The lower part of the stratigraphic sequence comprises a $1500 \mathrm{~km}$ thick carbonate and volcanogenic shales and volcanoclastic sandstones containing lenses and interlayers of gritstone and carbonaceous-cherty siltstones. The upper part of the sequence consists of $600-800 \mathrm{~m}$ thick sandstone with layers of carbonaceous siltstones with fossil remains of Prinadacopteris aff. Sibirica (Zal.) Radcz., Neuropteris dichotoma Neub., Gondwanidium sibicium (Pet.) Zal. Carbonaceous-terrigenous sequences are cut through by a magmatic formation (depth $3-3.5 \mathrm{~km}$ ), which is paragenetically associated with ore mineralization, and within its single stocks and numerous dikes of plagiogranite porphyries, and diorite porphyries forming belts of the northwestern and sublatitudinal strike (Rafaylovich et al. 2011; Umarbekova et al. 2017b).

\section{Samples and methods}

\subsection{Sampling and analytical method}

A total of nine rock samples were selected for analytical and experimental observation from the organic-rich sedimentary bedrocks, from three mineralization zones, located near the shear zone in the open pit (see Fig. 2a). The first three samples relate to the lower zone of pre-ore mineralization, the second three represent the main ore mineralization zone, and the last three samples of the third group were collected from the upper surface zone of post-ore mineralization.

The first three samples (group I) (Bak 2; Bak 1; Bak 2.5) are carbonaceous-siltstone rocks; the next three samples of the second (group II) (Bak 2.2; Bak 2.3; Bak 2.1) are arsenic sulfide-rich carbonaceous-siltstones and the last three samples (group III) (Bol; Bak 2.4; Bak 2.25) of the third (III) group are antimony sulfide-rich carbonaceoussiltstone rocks (shown below in Fig. 2b).

Petrographically, all samples are of unmetamorphosed dark siltstones containing a high amount of solid pyrobitumen and dispersed arsenian pyrite and arsenopyrite appearing in quartz veins within authigenic clay particles. The solid pyrobitumen in its host rocks fills in veinlets and veins of quartz showing black color, medium metallic luster, and has a brittle, partly flaky structure. Its density is less than $2 \mathrm{~g} / \mathrm{cm}^{3}$ and hardness is between 2.5 and 3 (in Mohs scale).

Polished specimens mounted in epoxy resin were prepared from the rock samples enriched with solid pyrobitumen and sulfide ore minerals for optical microscopy, electron microprobe analysis (EMPA), and Raman microscopy.

For analytical measurements, the samples were crushed into powder $(10 \sim 50 \mu \mathrm{m})$ in a tungsten carbide ring mill and then in an agate mortar, homogenized, and portioned for further measurements. X-ray fluorescence (XRF), X-ray powder diffraction (XRPD), and Soxhlet extraction were performed for each sample. Carbonate-free powders were used for the Fourier-transform infrared spectroscopy (FTIR) with an attenuated total reflectance (ATR) attachment and organic elemental analysis (OEA) after removing inorganic carbonate minerals with $10 \%$ chloric acid. Bulk and sequentially separated samples were analyzed for gold concentration by inductively coupled plasma-optical emission spectroscopy (ICP-OES, 720 ES made by VARIAN Inc., Arial Plasma-view, simultaneous multi-element 

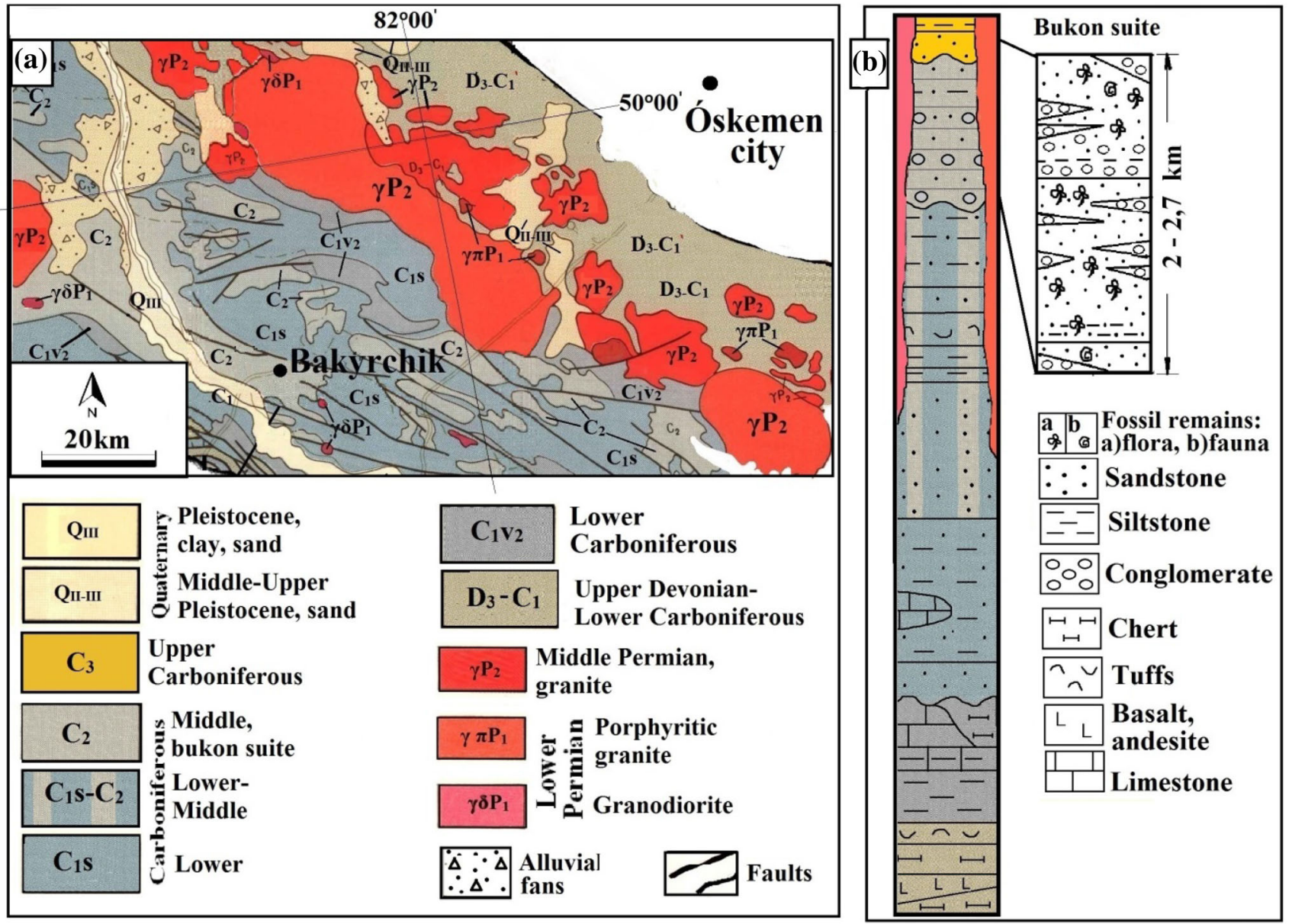

Fig. 1 Geological map of the Bakyrchik gold deposit (a) and stratigraphic column with lithological facies of the Bukon suite of the deposit (simplified after Trubnikov 1976; Seitmuratova et al. 1997; Umarbekova et al. 2017a). (complied by CorelDRAW Graphics Suite X6)

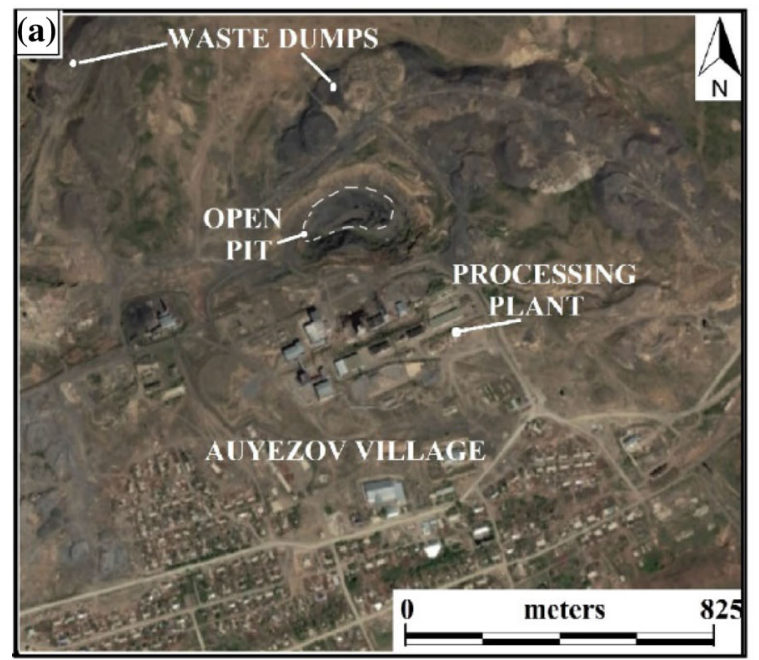

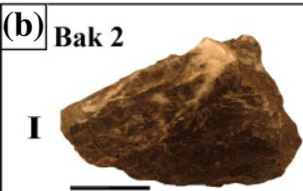
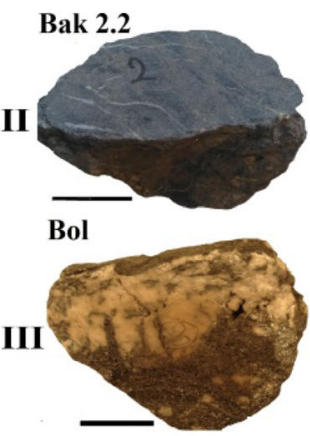
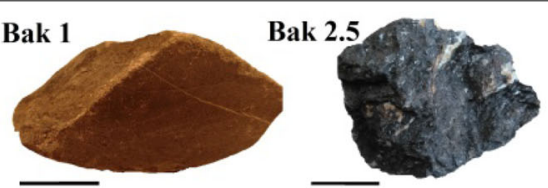

Bak 2.3
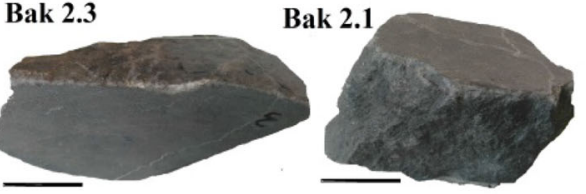

Bak 2.4

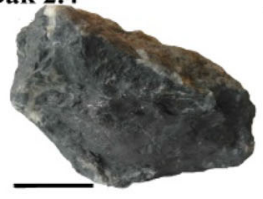

Bak 2.25

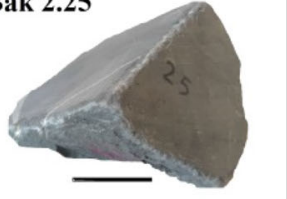

Fig. 2 Overview map of the study area (a) showing the sampling area marked with dashed lines and fragments of nine samples (b) from the three separate groups. (complied by Google Earth Pro and Adobe Photoshop CS3) 
ICP spectrometer) during the experiment, described more in chapter 3.2.

Reflected-light organic petrography was performed on a Zeiss UMSP 50 microscope, using $50 \times$ oil immersion lenses (R.I. of the oil $=1.5180$ ). A Zeiss AxioImager (A2m) microscope was used for imaging in incident normal and fluorescence light.

The electron microprobe analysis (EMPA) with backscattered electron (BSE) imaging, energy dispersive spectroscopy (EDS), and X-ray mapping was carried out on a JEOL SXA 8600 Superprobe (20 keV and $20 \mathrm{~mA}$ ), for elemental analysis of the arsenic content in pyrite; as well as for sulfur, chlorine and phosphorous content in the organic phase.

Thermal maturity of the organic matter was characterized by Raman microscopy (Thermo Scientific DXR Raman Microscope $532 \mathrm{~nm}$ Nd-YAG solid-state laser and OMNIC for Dispersive Raman 8.3.104 software), acquiring 47 measurement points focused on the three petrographically different types of organic materials of the whole rock samples and for one demineralized concentrated kerogen sample. The demineralization of kerogen was carried out with removals of carbonates using $10 \% \mathrm{HCl}$ (for $2 \mathrm{~h}$, at $60{ }^{\circ} \mathrm{C}$ in a water bath), and silicates and quartz minerals using $40 \% \mathrm{HF}: 10 \% \mathrm{HCL}\left(3: 1\right.$, for $5 \mathrm{~h}$, at $\left.70{ }^{\circ} \mathrm{C}\right)$ into a platinum dish and then the kerogen was separated physically from sulfide minerals into a sodium polytungstate heavy liquid. The Raman measurements were collected on orderly oriented organic phases acquiring 5-10 spectra for each sample. The laser beam was focused to a width of about $0.9 \mu \mathrm{m}$ with a $100 \mathrm{X}$ objective varying to $10 \times$ and $50 \times$ due to the sizes of organic materials. The numeric aperture (NA) of objective was 0.90 . The beam was aimed perpendicular to the polished section. The peak measurements were collected in the $500-3500 \mathrm{~cm}^{-1}$ range in the first-order and second-order regions.

Total organic carbon (TOC) and organic molecular structure were analyzed by OEA (ELTRA's CS-2000) and FTIR (FTS-14) with ATR; amorphous matter and mineral inclusions were determined by XRPD (BRUKER D8 ADVANCE Cu-K $\alpha 40 \mathrm{kV}, 40 \mathrm{~mA}$ ), and selected elemental composition of minerals was measured by XRF (WDXXRF (RIGAKU Supermini Pd source, $50 \mathrm{kV}-4 \mathrm{~mA}$ ).

$100 \mathrm{~g}$ of powdered samples were extracted into a cellulose thimble of the Soxhlet apparatus (Büchi B-811) with a mixture of dichloromethane $(837 \mathrm{~mL})$ and methanol $(63 \mathrm{~mL})$ at $46{ }^{\circ} \mathrm{C}$ for 3 days. Due to the low organic carbon content, the extracts were not separated further into fractions of saturated and aromatic hydrocarbons.

All the above-mentioned petrolography, analytical instruments, and laboratory works were carried out at the University of Miskolc, except for the Raman measurement which was carried out at the University of Szeged, Hungary.

\subsection{Experimental method}

A three-step sequential extraction method to remove gold from soluble fractions in nine samples was chosen for the experiment. The experiment has been performed by many authors (Beckett 1989; Davidson et al.1999; Liang et al. 2016) to extract and evaluate heavy metals associating with sulfide and organic fractions.

The experiment was performed by a three-step sequential extraction method (Dold and Fontbote 2001; Usmanova et al. 2017). Experimental materials comprised a test tube rack (woody), funnel, and $11 \mathrm{~cm}$ diameter of filter paper (Filtrier-Papier Nr. 5893 Blauband Marke SelectaGermany) for filtration procedures and an oven for drying fractions after filtration on each stage and the chemical reagents of hydroxyl ammonium chloride $\left(\mathrm{NH}_{2}-\mathrm{OH} \cdot \mathrm{HCl}\right)$, hydrogen peroxide $\left(\mathrm{H}_{2} \mathrm{O}_{2}\right)$ and aqua regia $\left(\mathrm{HNO}_{3}+\mathrm{HCl}\right)$ provided by the Chemical Department of Miskolc University. For the experiment, samples were selected containing the largest amount of organic matter and arsenic sulfide-rich minerals from the nine rock samples. They were separately crushed to a size of less than $63 \mu \mathrm{m}$, using an agate mortar and pestle. Size reduction of samples was done by the method of coning and quartering. After the crushing process, powder samples consisting mostly of organic matter and arsenic sulfide minerals have weighed a maximum of $5 \mathrm{~g}$ of every nine samples for the experiment.

At the first stage, for dissolving iron oxide and sulfides, $5 \mathrm{~g}$ of powder samples were added to and mixed manually with $45 \mathrm{~mL}$ of $1 \mathrm{M} \mathrm{NH} \mathrm{NH}_{2} \mathrm{OH} \cdot \mathrm{HCl}$ (hydroxylammonium chloride) at $\mathrm{pH}$ 4.5. Then the tube was shaken for $2 \mathrm{~h}$ at room temperature. The extract was decanted into a plastic test tube. Then the residue was prepared for the next step by washing it with distilled water and left in the oven for drying at $60{ }^{\circ} \mathrm{C}$.

At the second stage, the purpose was to extract gold associate with organic matter. The residue of the sample from stage 1 was weighted; $2 \mathrm{~g}$ of powder was mixed manually with $18 \mathrm{~mL}$ of $30-35 \% \mathrm{H}_{2} \mathrm{O}_{2}$ (hydrogen peroxide) added into a glass beaker $(100 \mathrm{~mL})$. After the mixing process, the glass test tube was placed into a water bath at $85{ }^{\circ} \mathrm{C}$ water for $1 \mathrm{~h}$. After this procedure, it was decanted and filtrated, to divide liquid extracts and solid residues. The residue materials were kept for the third step.

At the third stage (for sulfide minerals, mostly arsenopyrite), the residue material from the first step was weighed; $1 \mathrm{~g}$ of the powder samples was mixed with $9 \mathrm{~mL}$ aqua regia $\left(68 \% \mathrm{HNO}_{3}-37 \% \mathrm{HCl}, 1: 3\right)$. Then the mixture was placed into a water bath at $100{ }^{\circ} \mathrm{C}$ for $1 \mathrm{~h}$. After finishing, the liquid extract was filtered as in the former 
process, ready to measure, the gold extraction from arsenic sulfide minerals. The liquid extracts of three steps were measured by ICP-OES for gold and other precious metals concentrations. The residues of extracts were examined by XRPD in a presence of an amorphous and mineral phase.

\section{Results}

\subsection{Petrography}

The nine rock samples are of the non-metamorphosed origin of clay minerals and contain typical sulfide and organic-rich sedimentary rock minerals: XRPD values show muscovite (average 10.5 wt.\%), albite (average 5 wt.\%), and illite (with low-grade smectite, general average 17 wt.\%), hydrothermal carbonate minerals (ankerite and siderite, general average $16 \mathrm{wt} . \%$ ), and quartz. Quartz is found as vein and veinlets which penetrate diagonally into laminated clay minerals as secondary minerals, indicating a hydrothermal origin. Hydrothermal quartz is found in an average of $25.1 \mathrm{wt}$ \% in bulk samples and paragenetically associated with the arsenic sulfide ore minerals, antimony minerals, and solid pyrobitumen as veins and veinlets in clay seams (see in Fig. 3a, b and Table 1).

The solid pyrobitumen appears mostly in two types of veins (see in Fig. 3b) and its content varies between 8 and 14 wt.\% (average 11 wt.\%, shown in Table 1) in all three groups (except vitrinite, presented in Bak 1, Bak 2.1, and Bak 2.5) of samples. It has an amorphous structure (described more in detail in the next chapter). The solid pyrobitumen of samples in thin sections is opaque, and it appears as dark and partly brownish-grey fillings of veins and veinlets. Usually, it is optically isotropic or weakly anisotropic.

The solid pyrobitumen appears as flow-like textures and covers quartz grain boundaries with very narrow (less than $1 \mu \mathrm{m})$ to broad $(\sim 0.25 \mathrm{~mm})$ rims, filling in voids and microcracks or forming lenses showing the results of migration.

\subsection{Organic petrology}

The organic matter found in all nine samples is represented by dark brown to grayish color veined pyrobitumens (denoted as PB1 and PB2) and by reworked vitrinite as trapped and cracked, angular-shaped maceral in the middle of the hydrothermal fracture zone. The pyrobitumen has fracture- and void-filling textures showing two different microscopic features. The two veined pyrobitumens can be distinctly recognized under fluorescent light excitation: one has light brownish-grey fluorescence (PB1), while the other has a dark brown color in reflected white light and is non- fluorescing (PB2). This later occurs in large fractures and voids of quartz (found in all samples).

The two veined pyrobitumens fill in two main quartz veins of different sizes. The fluorescing PB1 bitumen occurs as a diffuse bituminous matrix or a continuous pretty thin membrane on the quartz, which is adhered also to the wall rocks. This pyrobitumen type usually occurs on the majority of quartz veins (Fig. 4).

The non-fluorescing (PB2) pyrobitumen is a discontinuous membrane filling the veins with a diameter smaller than $0.5 \mu \mathrm{m}$, adhered to wall rocks (Fig. 4).

The two pyrobitumens are closely associated with sulfide ore minerals in hydrothermal quartz veins and veinlets. Two pyrobitumens occur in the veinlets like patches of diffused pyrobitumen or following the grain boundaries (Fig. 4a, b).

The reworked vitrinite $(\mathrm{V})$ is characterized as cracked smaller vitrinite particles of more- or less linear character and parallel with the fracture orientation, locating in the middle of large voids later filled by spheroidally growing quartz. This reworked vitrinite appears relatively rarely; it occurs in the first and second groups of samples (found only in three samples of Bak 1, Bak 2.1, and Bak 2.5). In the reworked vitrinite framboidal pyrite also occurs (Fig. 4a). The elemental content of the reworked vitrinite obtained by EMPA is shown in detail below in chapters 4.4 and 4.5 .

\subsection{Ore mineralogy}

The ore microscopic observations show that the samples have ore mineral assemblages of gold-bearing arsenian pyrite and arsenopyrite, stibinite, and valentinite. The arsenic pyrite was found in cubic and hexahedral textures while arsenopyrite mineral in the samples had a twin-tabular and acicular form (see Fig. 5a, b). The antimony ore minerals are stibnite and valentinite, found in the open space of hydrothermal quartz veins in the form of overgrowths of fibrous textures (shown in Fig. 5c). Free gold was not detected in samples under optical microscopy.

The arsenic sulfide ore minerals were found mostly in the three samples of the second group; they always occur alongside the veins of hydrothermal quartz (Figs. 3 and 5a). The amount of arsenian pyrite varies between 1.5 and 32.7 wt.\% (average 7.7 wt.\%), while the amount of arsenopyrite varies between 1.5 and $12.5 \mathrm{wt} . \%$ (average 4.2 wt.\%). The antimony minerals have values between 3.9 and $7.7 \mathrm{wt} . \%$ (average $6.5 \mathrm{wt} . \%$ ), found only in three samples of the third samples group, related to the upper surface zone of mineralization (see in Table 2). Maximum arsenic content up to $35,185 \mathrm{ppm}$ in the second sample group and the lowest value is $346 \mathrm{ppm}$ in the third group of samples while the antimony shows the highest value up to 

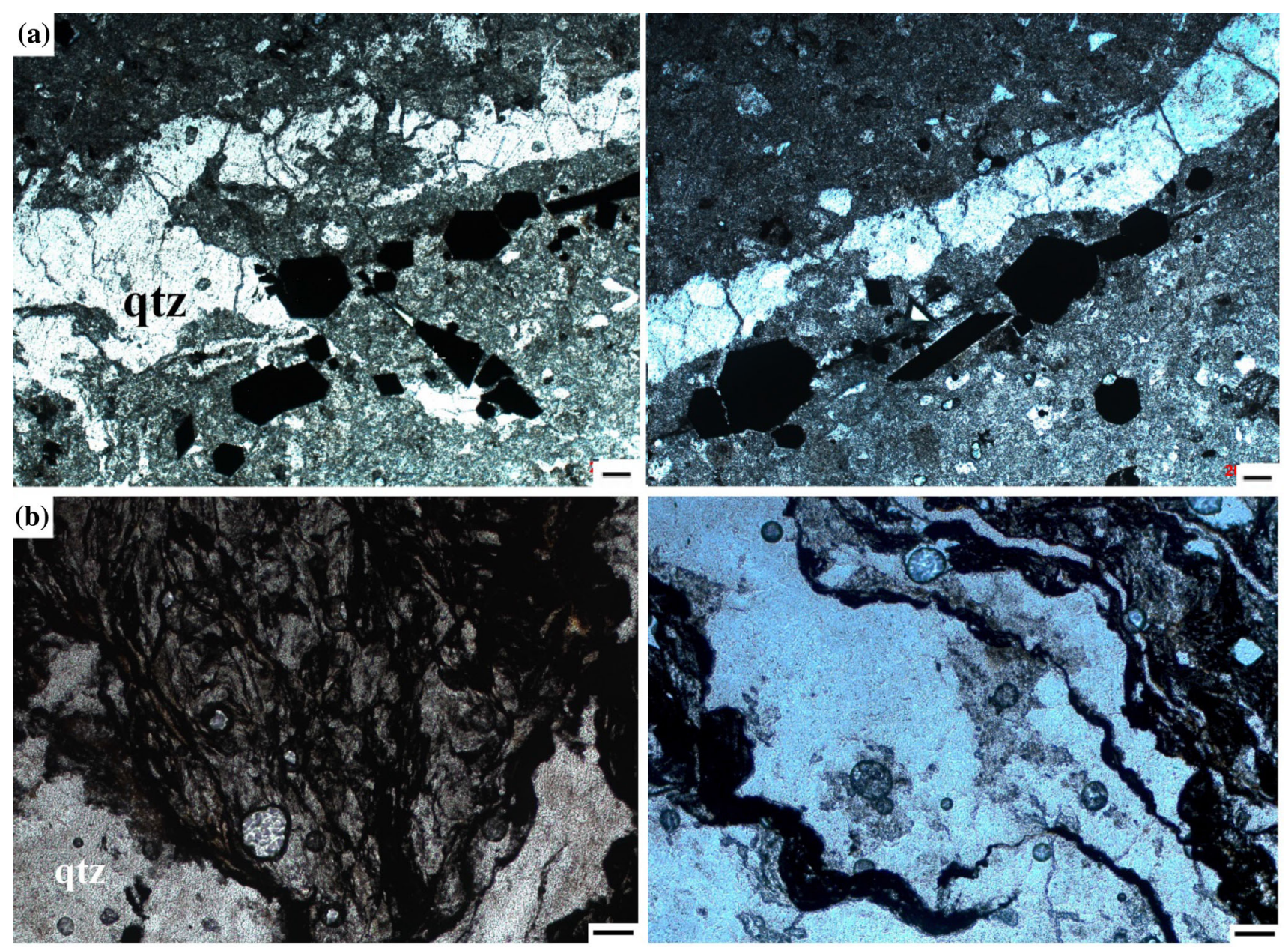

Fig. 3 Transmitted microscopy images under plane-polarized light of hydrothermal quartz veins (qtz) with a arsenic sulfide ore minerals and b typical pyrobitumen in the samples Bak 2.5. Scale: $0.2 \mathrm{~mm}$

Table 1 Quantitative results for rock minerals and amorphous matter from nine samples (unit, $\mathrm{wt} \%)$

\begin{tabular}{llllllllll}
\hline Group & Samples & Am & Qtz & Mus & Alb & Ank & Sid & Sme & Ill \\
\hline \multirow{4}{*}{ I } & Bak 2 & 14 & 24 & 20 & 2.9 & - & 38.5 & - & - \\
& Bak 1 & 10 & 15.8 & 32.8 & 20.8 & 3.3 & 6.3 & 2.4 & 9.8 \\
& Bak 2,5 & - & 41.5 & - & - & - & - & - & 25.3 \\
II & Bak 2,2 & 12 & 25 & - & 0.1 & 3.4 & - & 14.4 & - \\
& Bak 2,3 & 14 & 31 & - & 2.6 & 2.8 & - & - & 17.4 \\
& Bak 2,1 & 8 & 41.2 & 7.9 & 13.3 & 2.7 & - & - & 21.3 \\
III & Bol & 8 & 63 & 13.7 & 0.4 & - & - & - & 25.3 \\
& Bak 2,4 & - & 80.4 & - & 0.7 & - & - & - & 9.8 \\
& Bak 2,25 & 9 & 36 & 9 & 15.3 & 2.2 & - & - & - \\
\hline
\end{tabular}

Am amorphous matter, $Q t z$ quartz, $M u s$ muscovite, Alb albite, Ank ankerite, Sid siderite, Sme smectite, Ill illite 

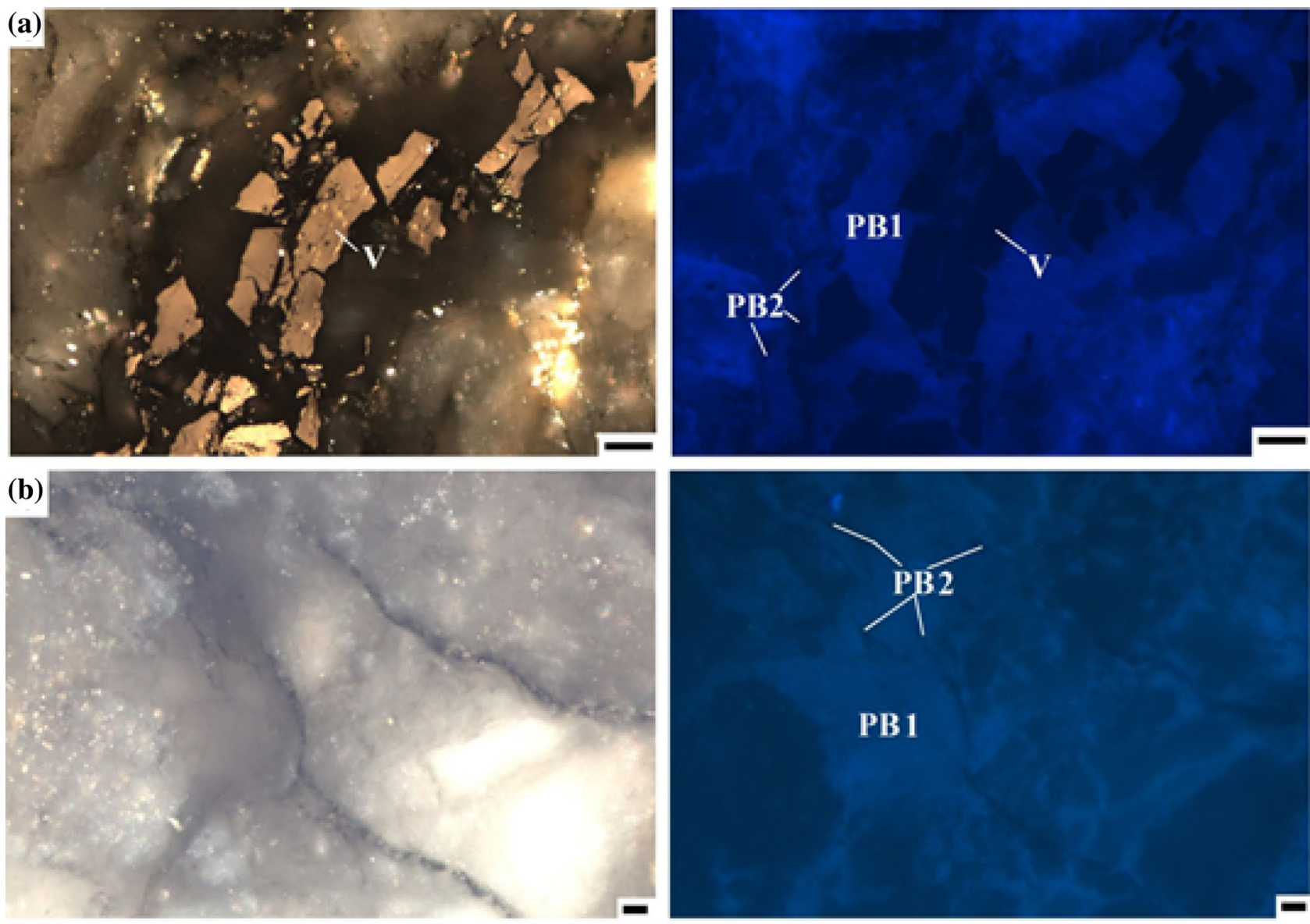

Fig. 4 Photomicrographs of solid pyrobitumen (left is normal reflected light and right is ultraviolet excitation in oil immersion) filling in hydrothermal quartz veins: reworked vitrinite (V) associated with fluorescing brownish grey (PB1) and non-fluorescing dark brownish solid pyrobitumen (PB2) and pyrite; b fluorescing coating. Right: parallel polarized light in oil immersion. Left: ultra-violet fluorescent excitation of diffused and fractured solid pyrobitumen filling (PB1) associated with non-fluorescing solid pyrobitumen (PB2). Right: parallel polarized light in oil immersion. Left: ultra-violet fluorescent excitation. Scale: $10 \mu \mathrm{m}$
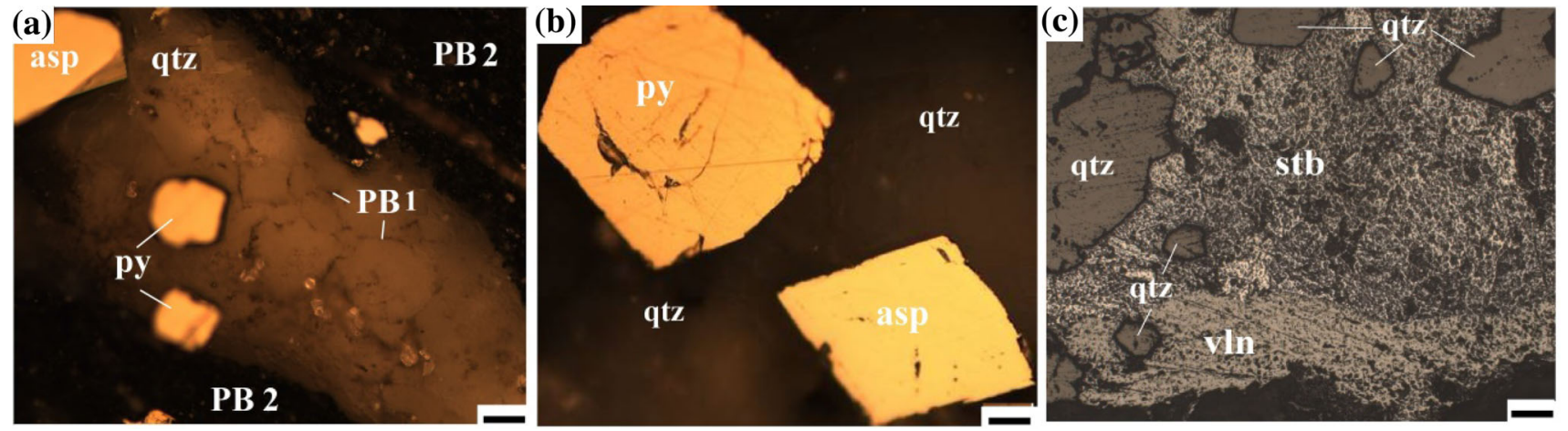

Fig. 5 Photomicrographs of ore microscopy: a cubic pyrite (py), acicular arsenopyrite (asp), and pyrobitumen (PB2 and PB3) occurring within hydrothermal quartz veins; b hexahedral pyrite (py) and tabular arsenopyrite (asp) in quartz veins (qtz); c stibnite and antimonite into quartz veins (qtz). Scale: $10 \mu \mathrm{m}$ 
Table 2 Mineralogical and chemical compositions of sulfide ores in three groups of nine samples

\begin{tabular}{|c|c|c|c|c|c|c|c|c|c|c|}
\hline \multirow[t]{2}{*}{ Group } & \multirow[t]{2}{*}{ Label } & \multicolumn{4}{|c|}{ Minerals (unit, ppm) } & \multicolumn{5}{|c|}{ Chemical elements (unit, ppm) } \\
\hline & & ap & py & st & $\mathrm{vl}$ & As & $\mathrm{Sb}$ & $\mathrm{Cu}$ & $\mathrm{Zn}$ & $\mathrm{Pb}$ \\
\hline \multirow{3}{*}{ I } & Bak 2 & - & - & - & - & 956 & - & 16 & 97 & 835 \\
\hline & Bak 1 & - & - & - & - & 1537 & - & 42 & 61 & 1304 \\
\hline & Bak 2,5 & - & - & - & - & 4018 & 102 & 55 & 104 & 17 \\
\hline & Bak 2,2 & 12.5 & 32.7 & - & - & 34,520 & 124 & 46 & 17 & 15 \\
\hline \multirow[t]{3}{*}{ II } & Bak 2,3 & 10.3 & 21.4 & - & - & 35,185 & 241 & 39 & 29 & 11 \\
\hline & Bak 2,1 & 2.2 & 2.9 & - & - & 17,098 & 88 & 51 & 218 & 27 \\
\hline & Bol & - & 2.6 & 7.7 & 3.9 & 346 & - & 18 & - & 336 \\
\hline \multirow[t]{2}{*}{ III } & Bak 2,4 & - & - & 5.2 & 3.9 & 1902 & 137,000 & 23 & 10 & 35 \\
\hline & Bak 2,25 & 1.5 & 1.4 & - & - & 13,100 & 50 & 24 & 100 & - \\
\hline
\end{tabular}

$A p$ arsenopyrite, $P y$ pyrite, $S t$ stibnite, $V l$ valentinite
$137,000 \mathrm{ppm}$ in the third group of samples (shown in Table 2). The elemental compositions of the sulfide ore minerals are described below.

\subsection{Microprobe analysis for reworked vitrinite and ore minerals}

Microprobe analysis is carried out for reworked vitrinite grains and two other vein types of pyrobitumen. Other authors also mentioned the detection limit problem (Belin 1994; Cardott 2007). Pyrite growing over the reworked vitrinite appears in globular framboids or sometimes polyframboids was found only in the first group of samples. The framboidal pyrite is of sedimentary-digenetic origin with a diameter of 2-50 micron, showing no presence of arsenic (Fig. 6). The reworked vitrinite contains more than $90 \mathrm{wt} . \%$ carbon element and oxygen of 4-6 wt.\%.

Moreover, the reworked vitrinite has a relatively higher S content, between 0.78 and $1.27 \mathrm{wt} . \% \mathrm{P}(0.15-0.19)$ and
$\mathrm{Cl}(0.09-0.12$ wt.\%). Fe is detected as 0.23 wt.\%, while Ti varies between 1.19 and $2.77 \mathrm{wt} \%$ in some samples.

$\mathrm{Si}$ is detected up to $0.32 \mathrm{wt} . \%$ and $\mathrm{Al}$ is up to $0.25 \mathrm{wt} . \%$, and with minor amounts of $\mathrm{K}$ and $\mathrm{Mg}$ in the range of $0.08-0.17$ wt.\% present in organic matter. The minor amounts of $\mathrm{Si}, \mathrm{Al}, \mathrm{K}$, and $\mathrm{Mg}$ are most likely present in the reworked vitrinite, due to the vicinity of the rock minerals.

Framboidal pyrites occur up to $8 \mu \mathrm{m}$ in reworked vitrinite grains, where they are enriched in $\mathrm{Zn}$ up to 0.43 wt.\%, As to 0.46 wt.\%, and $\mathrm{Sb}$ to 0.49 wt.\% in some samples. This indicates that framboidal pyrites are of a hydrothermal origin as a co-precipitation.

Additionally, using EMPA-EDS, 66 points were analyzed on the surfaces of individual arsenic sulfide crystals in polished sections for the detection of gold and arsenic elements (part of analytical points on grains shown in Fig. 7). The EDS results show varying chemical concentrations within different morphogenetic shapes and sizes. Cubic and hexahedral shapes of pyrite were found in the
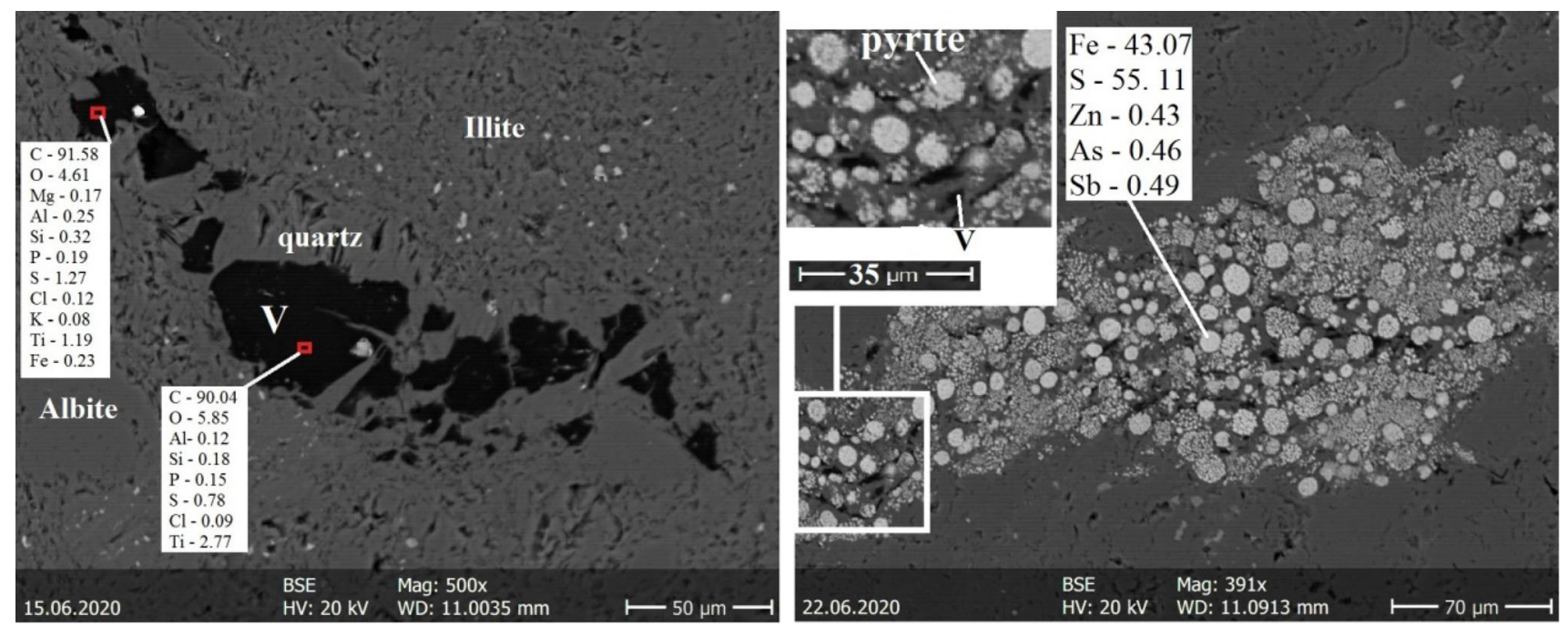

Fig. 6 BSE images showing the chemical composition of vitrinite (V) and growths of framboidal pyrites on the vitrinite (unit wt.\%) 

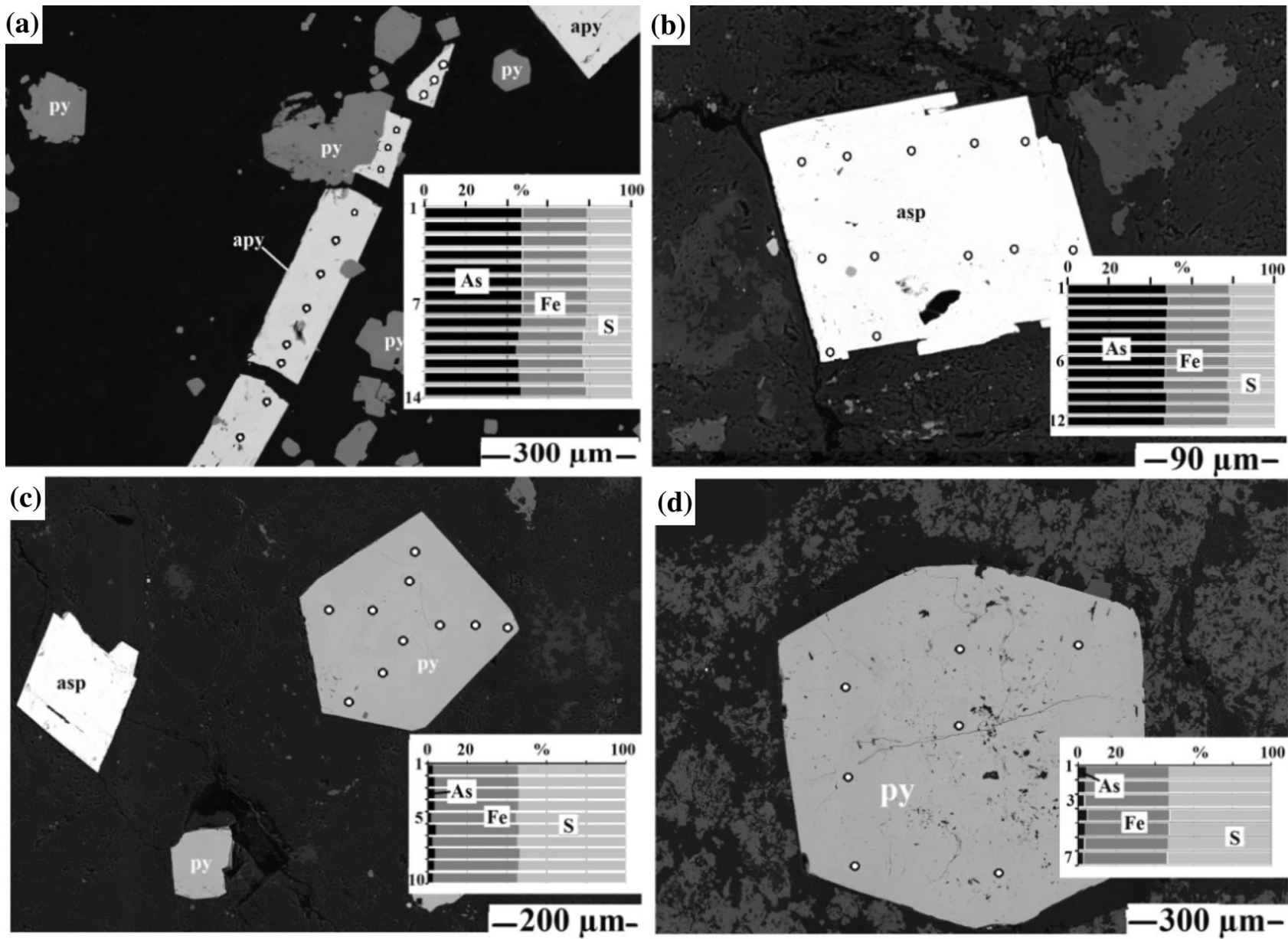

Fig. 7 Photomicrograph of arsenopyrite and arsenian pyrite analysis on the chemical compositions (point analysis) of crystal grains for different textures. a Acicular grains of arsenopyrite; $\mathbf{b}$ tabular-twin grains of arsenopyrite; $\mathbf{c}$ pentahedral grains of pyrite crystal with tabular-arsenopyrite twin; d hexahedral grains of pyrite crystal

samples of the second group. They are of hydrothermal origin with $0.15-0.5 \mathrm{~mm}$ in size. Arsenic was found in the cubic pyrite between 0.97 and 3.68 wt.\% (average 2.32 wt.\%) and 2.7-4.86 wt.\% (average $3.78 \mathrm{wt} . \%$ ) in the hexahedral pyrite. Gold was not detected in these pyrite grains.

Arsenopyrite crystal has twin-tabular and acicular forms in the second group of samples. The average size of the twin-tabular arsenopyrite crystal is $0.2 \mathrm{~mm}$ and the acicular crystal is between 0.6 and $1 \mathrm{~mm}$ in length and about 75 microns in width. Arsenopyrite has an apparent arsenic content of over 42 wt.\% and has no detected gold inclusions.

Antimony content is measured over $80 \mathrm{wt} . \%$ in valentinite and less than 73 wt.\% in stibnite. These minerals have no arsenic and gold inclusions.

\subsection{X-ray maps of sulfur content for reworked vitrinite}

EMPA X-ray map shows that organic sulfur covers reworked vitrinite grains (Fig. 8a, c). Several light white spots on the reworked vitrinite show growths of individual sulfide crystals of sphalerite and pyrite in the map (Fig. 8b). The reworked vitrinite includes globular pyrite up to $5 \mu \mathrm{m}$ in size (denoted as pyrite 1 in Fig. 8b), containing relatively lower amounts of arsenic (1.02 wt.\%), and the absent elements of copper, zinc, and antimony, which are present in the acicular form, and crystal-shaped pyrite with a size of $30 \mu \mathrm{m}$ (designated as pyrite 2 in the Fig. 8b). Reworked vitrinite occurs also in intergrowths with tiny globular sphalerite grains, $3-5 \mu \mathrm{m}$ in size (Fig. 8b). 

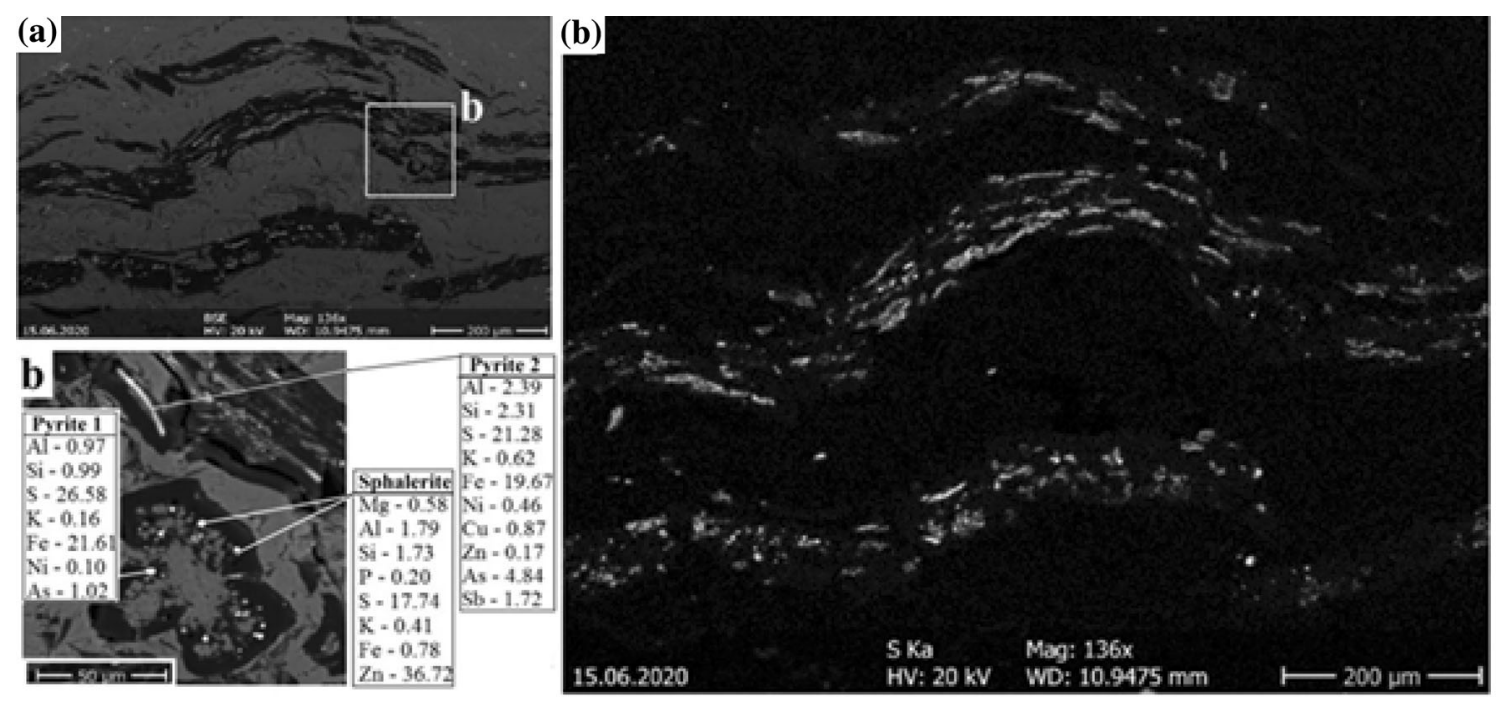

Fig. 8 EMPA-EDS X-Ray map for vitrinite: BSE image (a) and EDS measurements; b sulfur mapping image in thin-walled fly ash, an inertinite particle (c) (unit wt.\%)

\subsection{Thermal maturity and reflectance}

The results of micro-Raman spectroscopy for two types of solid pyrobitumen, the vitrinite, inertinite macerals, and, additionally, the kerogen was focused on the first-order region, which associates with two bands (D and $G$ ) between 1350 and $1600 \mathrm{~cm}^{-1}$, and on the second region being associated with up to three bands (S) between 2600 and $3500 \mathrm{~cm}^{-1}$, following the studies of Jehlicka et al. (2003) and Kouketsu et al. (2014). The Raman results indicate pyrobitumen with bituminous structure in the samples, which can be correlated with the structural evolution of bitumen from Zbečno (Czech Republic) and Karelia (Russia) in the study of Jehlicka et al. (2003). The Raman measurements concentrate on three parameters; the position of peaks, intensity, and full width at half maximum (FWHM), which is based on Kouketsu's (2014) equation, see Eq. 1 below:

$\mathrm{T}\left({ }^{\circ} \mathrm{C}\right)=-2.15(\mathrm{FWHM}-\mathrm{D} 1)+478$

where $\mathrm{T}=$ estimated temperature; FWHM = full width at half maximum; D1 = a peak of Raman spectra.

The equation is used to estimate the thermal maturity of carbonaceous matter because it is applicable and accurate in the range of $200-400{ }^{\circ} \mathrm{C}$ (Kouketsu et al. 2014). The quantitative Raman measurement shows that multiple spot analyses of different areas in the samples of three types of carbonaceous matter and kerogen provided similar spectra (" $n$ " means the numbers of spectra), showing relatively intensive bands of D $\left(1331-1338 \mathrm{~cm}^{-1}\right)$ and $\mathrm{G}$ $\left(1600-1604 \mathrm{~cm}^{-1}\right)$, while D3 $\left(1500 \mathrm{~cm}^{-1}\right)$ and D4 $\left(1180 \mathrm{~cm}^{-1}\right)$ are quite weak bands in the first-order region, and $\mathrm{S}$ bands (between 2600 and $3300 \mathrm{~cm}^{-1}$ ) have a relatively low intensity in the second-order region. The three types of carbonaceous matters and kerogen are described separately below (shown in Fig. 9 and Table 3):

Kerogen is characterized by a low intensity wide (up to $118.6 \mathrm{~cm}^{-1}$ FWHM) D1 band at around $1332.9 \pm 8.7 \mathrm{~cm}^{-1}(\mathrm{n}=5)$, and a relatively high intensity narrow (up to $68.46 \mathrm{~cm}^{-1}$ FWHM) D2 band at $1601.0 \pm 11.57 \mathrm{~cm}^{-1}(\mathrm{n}=5)$. In the second-order region, the major peaks occur at wavenumbers of $2867.06 \mathrm{~cm}^{-1}$ (S1), $2914.31 \mathrm{~cm}^{-1}$ (S2) and $3065.69 \mathrm{~cm}^{-1}$ (S3) (Fig. 9a, d).

Reworked vitrinite $(\mathrm{V})$ is characterized by a low intensity wide (up to $117.64 \mathrm{~cm}^{-1}$ FWHM) D1 band at around $1331.6 \pm 9.6 \mathrm{~cm}^{-1}(\mathrm{n}=10)$ and a relatively high intensity narrow (up to $58.82 \mathrm{~cm}^{-1}$ FWHM) D2 band at $1603.9 \pm 6.75 \mathrm{~cm}^{-1}(\mathrm{n}=10)$. In the second-order region, the major peaks occur at wavenumbers of $2655.9 \mathrm{~cm}^{-1}$ (S1), $2913.35 \mathrm{~cm}^{-1}$ (S2), and $3219.87 \mathrm{~cm}^{-1}$ (S3) (Fig. 9a, b).

The first pyrobitumen (PB1) has a high intensity wide D1 peak (up to $109.92 \mathrm{~cm}^{-1} \mathrm{FWHM}$ ) at wavenumber of $1337.8 \pm 22.2 \mathrm{~cm}^{-1}(\mathrm{n}=5)$ and a low intensity, narrow D2 peak (up to $58.81 \mathrm{~cm}^{-1}$ FWHM) at wavenumber of $1601.0 \pm 7.7 \mathrm{~cm}^{-1}(\mathrm{n}=5)$ in the first region and the $\mathrm{S}$ peaks at wavenumbers of $2607.46 \mathrm{~cm}^{-1}$ (S1), $2922.98 \mathrm{~cm}^{-1}$ (S2) and $3191.1 \mathrm{~cm}^{-1}(\mathrm{~S} 3)(\mathrm{n}=5)$ in the second region (Fig. 9a, c).

The second pyrobitumen (PB2) exhibits a high intensity, relatively wide (up to $93.53 \mathrm{~cm}^{-1}$ ) D1 peak at around $1338.7 \pm 12.54 \mathrm{~cm}^{-1}(\mathrm{n}=5)$, while a low intensity, narrow (up to $49.18 \mathrm{~cm}^{-1}$ ) D2 peak at around $1602.9 \pm 5.8 \mathrm{~cm}^{-1}(\mathrm{n}=5)$ occurs in the first region. In the second region, the pyrobitumen has a weak S1-peak at 
Fig. 9 Raman microscopy measurement of reworked vitrinite $(\mathrm{V})$, two types of pyrobitumen $(\mathrm{PB})$ and kerogen with Raman spectra (a) of D and G peaks, and optical photomicrographs under crosspolarized light (b kerogen, c vitrinite, and d PB 1 and PB 2). Scale: $10 \mu \mathrm{m}$
Table 3 Relevant parameters of the Raman spectra of selected samples for estimated temperatures and estimated organic maturity

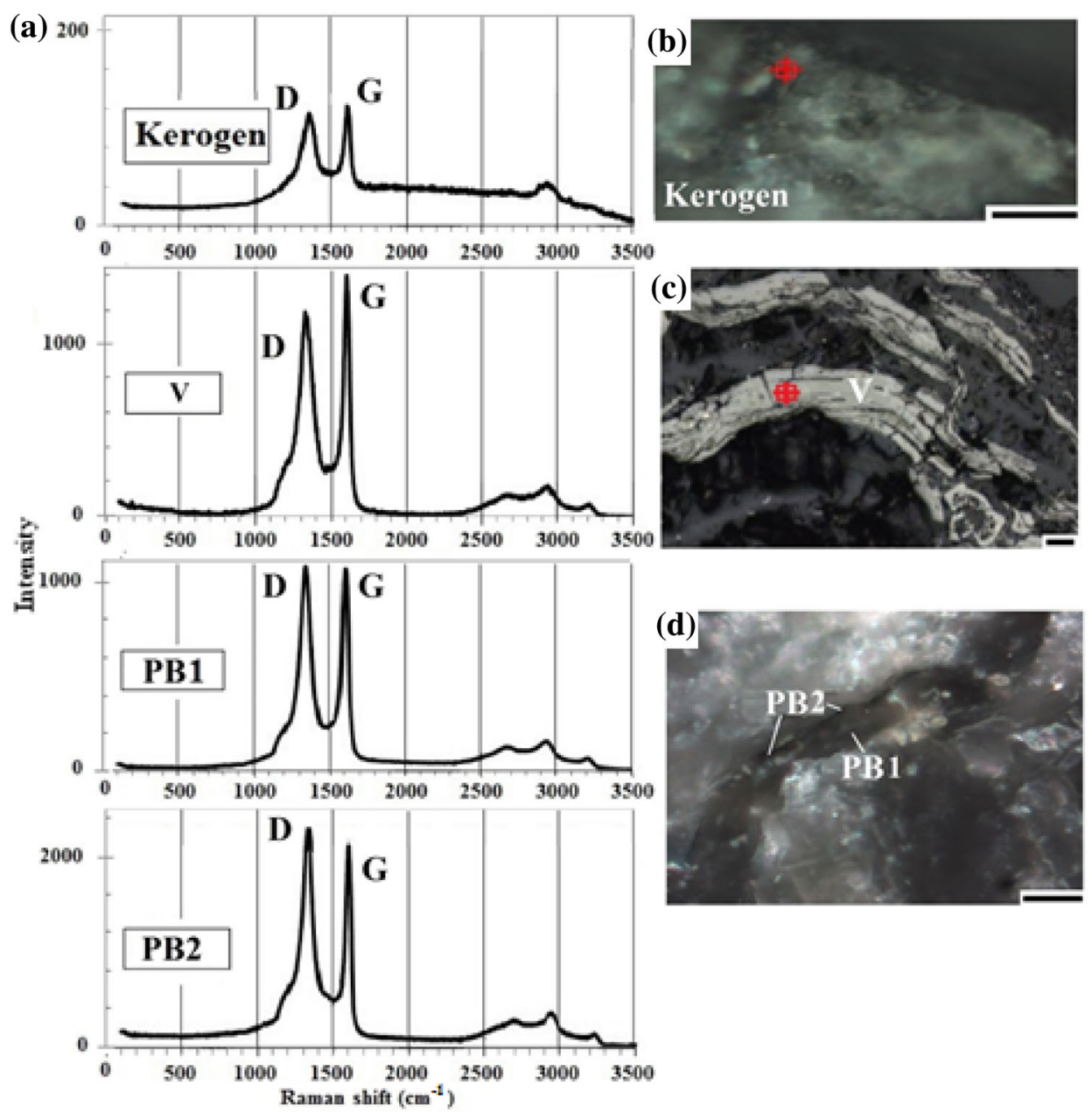

\begin{tabular}{lllllllll}
\hline OM & RP & $\begin{array}{l}\mathrm{P} \\
\left(\mathrm{cm}^{-1}\right)\end{array}$ & $\begin{array}{l}\text { FWHM } \\
\left(\mathrm{cm}^{-1}\right)\end{array}$ & PH & $\begin{array}{l}\text { Gi/Di } \\
\text { ratio }\end{array}$ & $\begin{array}{l}\text { Dh/Gh } \\
\text { ratio }\end{array}$ & RmcRo\% & $\begin{array}{l}\text { ToC } \\
( \pm 30)\end{array}$ \\
\hline $\mathrm{Kr}$ & $\mathrm{G}$ & 1601 & 56.88 & 158 & 1.032 & 0.968 & 3.88 & 231.3 \\
& $\mathrm{D}$ & 1332.9 & 114.74 & 153 & & & & \\
$\mathrm{~V}$ & $\mathrm{G}$ & 1603.9 & 55.92 & 1420 & 1.163 & 0.859 & 3.76 & 235.5 \\
& $\mathrm{D}$ & 1331.6 & 112.81 & 1220 & & & & \\
$\mathrm{~PB} 1$ & $\mathrm{G}$ & 1601 & 54.96 & 1165 & 0.978 & 1.021 & 3.94 & 254.1 \\
& $\mathrm{D}$ & 1337.8 & 104.14 & 1190 & & & & \\
PB2 & $\mathrm{G}$ & 1602.9 & 49.18 & 2200 & 0.956 & 1.045 & 3.97 & \\
& $\mathrm{D}$ & 1338.7 & 93.53 & 2300 & & & &
\end{tabular}

$O M$ organic matter, $K r$ kerogen, $V$ vitrinite, $P B$ pyrobitumen, $R P$ Raman peak, $P$ Position, $F W H M$ full width at half maximum, $P H$ Peak height, $G i / D i$ intensity ratio, $D h / G h$ peak height ratio, RmcRo\% Raman reflectance calculated using Raman parameters expressed in equivalent to vitrinite reflectance, $T$ Temperature around $2655.9 \mathrm{~cm}^{-1}(\mathrm{~S} 1)$ and two weak overtones at $2992.41 \mathrm{~cm}^{-1}(\mathrm{~S} 2)$ and $3203.58 \mathrm{~cm}^{-1}(\mathrm{~S} 3)$ are present (Fig. 9a, c).

The reflectance of pyrobitumen was determined by laser Raman characteristic peaks (peak height) using Liu's
(2013) equation, which is equivalent to vitrinite reflectance that can reflect different maturation grades and the surface optical properties of samples (Liu et al. 2013), see Eq. 2 below:

$\mathrm{RmcR}_{0} \%=1.1659 \mathrm{~h}(\mathrm{Dh} / \mathrm{Gh})+2.7588$ 
Fig. 10 FTIR analysis and comparison of organic fractions with the assignment of major peaks: a Molecular structure of lignin with silica nanocomposites (modified from Weizhen et al. 2017); b organic matter with rock matrices from the rock samples (a)

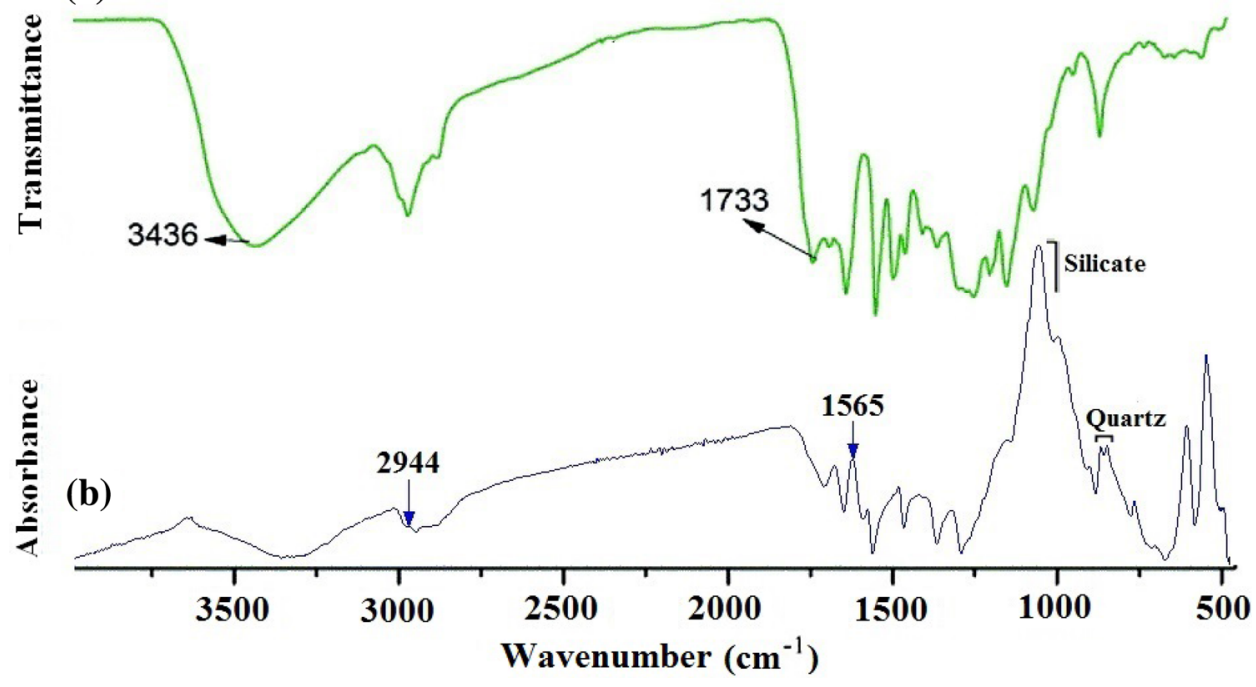

where $\mathrm{RmcR}_{0} \%$ refers to the Raman reflectance using Raman parameters; $\mathrm{h}(\mathrm{Dh} / \mathrm{Gh})$ refers to the Raman peak height ratio (Dh refers to the peak height $\mathrm{D}$, Gh refers to the peak height $G$ ).

The equation is more applicable for pyrobitumen (highly matured hydrocarbon with mineral inclusion) in an ore deposit (Liu et al. 2013; Yuguang 2017), which corresponds to our case.

In the samples, the equivalent reflectivity of three types of pyrobitumen and kerogen was calculated the maturity parameters of which are indicated in Table 3.

\subsection{Total organic content}

The total organic carbon (TOC \%) of the samples was measured in carbonate-free samples using an organic elemental analyzer after treatment with $10 \%$ chloric acid at room temperature and $60{ }^{\circ} \mathrm{C}$ for $20-30 \mathrm{~min}$ in water bath. The TOC found in various samples ranges from 0.31 to 0.47 wt.\% (0.36 wt.\%) in three groups of samples. The lowest TOC content was found in the sample Bak 2.25, which is $0.31 \mathrm{wt} . \%$, and no TOC was found in the Bol and Bak 2.4 samples from the third group which is related to the antimony sulfide ore zone (near-surface post-ore mineralization). Average TOC value ranges from 0.33 to 0.38 wt.\% in three samples (Bak 2.2, Bak 2.3, and Bak 2.1) of the second group related to the arsenic sulfide ore zone (the main ore mineralization), while the first group of the three samples (Bak 2, Bak 1 and Bak 2.5), belonging to the zone rich in the carbonaceous matter (pre-ore mineralization) shows the highest TOC content from 0.32 wt.\% to 0.47 wt.\% (see below in Table 4).

\subsection{Elemental composition, functional groups, and soluble organic matter analysis}

The organic elemental analyzer was used for the determination of the $\mathrm{C}, \mathrm{H}, \mathrm{N}$, and $\mathrm{S}$ content of the organic matter. Hydrogen contents range from 0.09 to $0.43 \mathrm{wt} . \%$ (average 0.26 wt.\%), while the nitrogen content varies from 0.15 to 0.26 wt. $\%$ (average $0.21 \mathrm{wt} . \%$ ) in the samples. Total sulfur content varies from 1.12 to $2.1 \mathrm{wt} . \%$, the average value is $1.61 \mathrm{wt} . \%$.

The composition of organic matter was determined using FTIR spectra (Fig. 10): a broad peak at $3375 \mathrm{~cm}^{-1}$ has stretching vibrations of hydroxyl $(\mathrm{O}-\mathrm{H})$ groups (very small amount), and methylene groups appear like antisymmetric stretching the peak at $2932 \mathrm{~cm}^{-1}$ and stretching the peak at $2854 \mathrm{~cm}^{-1}$, respectively. The peaks at $1632 \mathrm{~cm}^{-1}, 1525 \mathrm{~cm}^{-1}, 1497 \mathrm{~cm}^{-1}$, and $1282 \mathrm{~cm}^{-1}$
Table 4 Total organic carbon (TOC \%) of nine samples

\begin{tabular}{lllllllll}
\hline Samples & \multicolumn{1}{l}{} \\
\hline Bak 2 & Bak 1 & Bak 2,5 & Bak 2,2 & Bak 2,3 & Bak 2,1 & Bol & Bak 2,4 & Bak 2,25 \\
\hline 0.34 & 0.33 & 0.38 & 0.47 & 0.43 & 0.32 & - & - & 0.31
\end{tabular}


Table 5 Concentrations of extracted noble metals at the 3 stages (unit, ppm for Au and $\mathrm{Ag}$; ppb for Pt and Pd)

\begin{tabular}{|c|c|c|c|c|c|c|c|c|c|}
\hline \multirow[t]{3}{*}{ Noble metals } & \multicolumn{3}{|c|}{ Samples group I } & \multicolumn{3}{|c|}{ Samples group II } & \multicolumn{3}{|c|}{ Samples group III } \\
\hline & Bak & Bak & Bak & Bak & Bak & Bak & Bol & Bak & Bak 2,25 \\
\hline & 2 & 1 & 2.5 & 2.3 & 2.2 & 2.1 & & 2.4 & \\
\hline \multicolumn{10}{|c|}{ Stage 1 (pyrite) } \\
\hline $\mathrm{Au}$ & 0.1 & 0.13 & 0.09 & 0.08 & 0.05 & 0.13 & 0.01 & 0.1 & 0.05 \\
\hline $\mathrm{Ag}$ & - & - & 1.4 & 0.4 & 1.1 & 2 & - & 0.4 & 1.4 \\
\hline $\mathrm{Pt}$ & - & - & - & - & - & 130 & - & - & 100 \\
\hline $\mathrm{Pd}$ & - & - & - & - & - & - & - & - & - \\
\hline \multicolumn{10}{|c|}{ Stage 2 (solid pyrobitumen) } \\
\hline $\mathrm{Au}$ & 2 & 3 & 0.21 & 0.19 & 0.22 & 0.76 & 0.2 & 0.44 & 0.21 \\
\hline $\mathrm{Ag}$ & 1.7 & 1.7 & - & 0.12 & 0.01 & 0.32 & - & - & - \\
\hline $\mathrm{Pt}$ & - & - & 5 & - & 25 & - & - & - & 1 \\
\hline $\mathrm{Pd}$ & - & - & 10 & - & - & - & - & - & 16 \\
\hline \multicolumn{10}{|c|}{ Stage 3 (arsenopyrite) } \\
\hline $\mathrm{Au}$ & 0.5 & 4 & 0.11 & 0.81 & 1.26 & 2.1 & 0.4 & 0.43 & 0.48 \\
\hline $\mathrm{Ag}$ & 0.6 & 27 & 1,67 & 0.27 & 0.62 & 0.42 & - & 0.24 & 1.85 \\
\hline $\mathrm{Pt}$ & - & - & - & 105 & 139 & - & - & 19 & - \\
\hline $\mathrm{Pd}$ & - & - & - & - & - & - & - & - & - \\
\hline
\end{tabular}

Gold content accompanied with other metals (Ag, Pt, and $\mathrm{Pd}$ ) extracted by the sequential extraction from two different phases, soluble organic fractions of solid pyrobitumen and arsenic sulfide minerals from nine samples were measured by ICP-OES; see Table 5 .

In the first stage, the solvent of hydroxyl ammonium chloride started to extract the higher amount of As (180 ppm), Fe (3757 ppm), and S (132 ppm), most likely the dissolution of arsenian pyrite was removed with a precious metal content of gold (between 0.05 and $0.2 \mathrm{ppm}$ ), $\mathrm{Ag}$ (up to $1.4 \mathrm{ppm}$ ) and $\mathrm{Pt}$ (up to $130 \mathrm{ppb}$ ).

In the second stage, the amounts of dissolved precious metals in the nine samples exceeded the first stage. This solvent was strong enough to oxidize organic materials removing major amounts of precious metals: gold (7.23 ppm), $\mathrm{Ag}(3.8 \mathrm{ppm})$ and $\mathrm{Pt}(29.8 \mathrm{ppb})$, and $\mathrm{Pd}$ (10.4 ppb). Additionally, the presence of other elements in the extracts was found, such as As (over $4.5 \mathrm{ppm}$ ), Fe (over $9.4 \mathrm{ppm}$ ), S (over $175 \mathrm{ppm}$ ), and $\mathrm{P}$ (up to $88 \mathrm{ppm}$ ) at this stage.

In the last third stage, the most powerful aqua regia solvent completely dissolved all remaining precious metals from arsenopyrite and some remains of pyrite, and even norecoverable metals from the first stage. This stage shows the highest values for As (4000 ppm), Fe (14,285 ppm), S $(10,246 \mathrm{ppm})$, and the highest grade of $\mathrm{Au}(10 \mathrm{ppm}), \mathrm{Ag}$ (33 ppm), Pt (264), and Pd (16) were dissolved by the aqua regia solvent, most likely, from the arsenopyrite minerals (see below in Table 5).

The XRPD shows that each chemical element dissolved has corresponding phases in the three stages, with precious metals are very finely dispersed within the organic matrix. 
Table 6 Triangular diagram for gold to pyrobitumen and arsenic sulfide ores ratios

\begin{tabular}{|c|c|c|c|c|c|c|}
\hline \multirow{2}{*}{$\begin{array}{l}\text { Groups } \\
\text { (denoted in colors) }\end{array}$} & \multirow[t]{2}{*}{ Samples } & \multicolumn{2}{|c|}{ Parameters } & \multicolumn{3}{|c|}{ Au-bearing phases (unit, \%) } \\
\hline & & $\mathrm{x}$ & $\mathrm{y}$ & Pyrobitumen & Arsenopyrite & Pyrite \\
\hline \multirow{3}{*}{$\begin{array}{l}\text { I } \\
\text { (black) }\end{array}$} & Bak 2 & 77.09 & 42.05 & 76.92 & 19.23 & 3.85 \\
\hline & Bak 1 & 78.46 & 42.8 & 42.05 & 56.07 & 1.89 \\
\hline & Bak 2.5 & 52.72 & 51.49 & 51.49 & 26.97 & 21.54 \\
\hline \multirow{3}{*}{$\begin{array}{l}\text { II } \\
\text { (violet) }\end{array}$} & Bak 2.3 & 84.18 & 17.67 & 17.67 & 75.34 & 6.98 \\
\hline & Bak 2.2 & 89.71 & 14.41 & 14.41 & 82.51 & 3.09 \\
\hline & Bak 2.1 & 82.82 & 25.38 & 25.38 & 70.13 & 4.49 \\
\hline \multirow{3}{*}{$\begin{array}{l}\text { III } \\
\text { (red) }\end{array}$} & Bol & 81.97 & 32.79 & 32.79 & 65.57 & 1.64 \\
\hline & Bak 2.4 & 66.86 & 45.26 & 45.26 & 44.23 & 10.51 \\
\hline & Bak 2.25 & 79.53 & 28.55 & 28.55 & 65.26 & 6.19 \\
\hline Average & & & & 37.17 & 56.15 & 6.69 \\
\hline
\end{tabular}

Fig. 11 Triangular diagram of the gold in pyrobitumens, vitrinite, Arsenopyrite, and pyrite ratio in three sample groups of total nine samples (Denoted by color: black for group I; violet for group II, and red for group III)

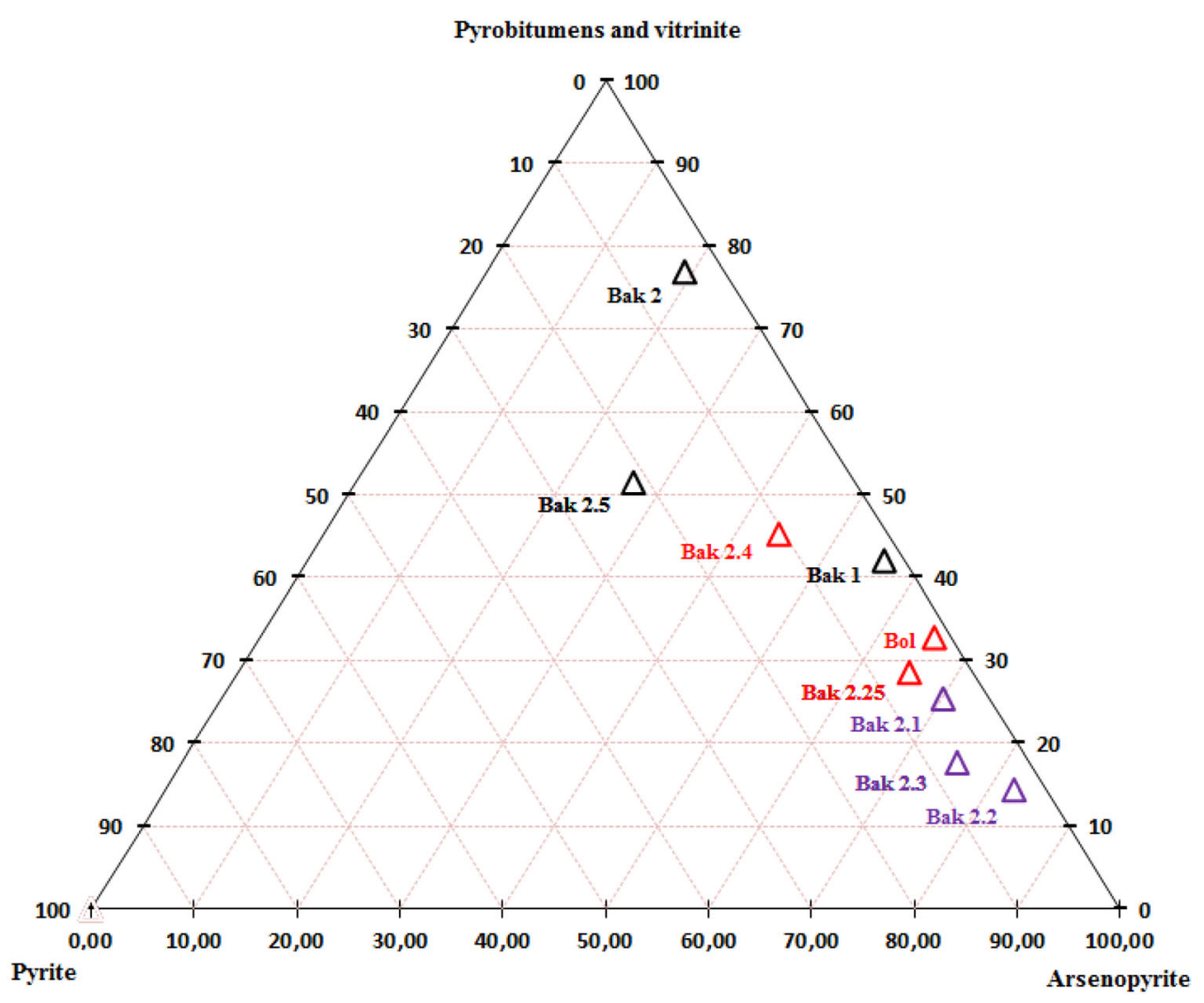

decreasing or completely lost phases of amorphous and mineral matters during the process of acid digestion.

The three groups of the nine samples have gold, Ag, Pt, and Pd contents with different values in organic matter and arsenic sulfide ore minerals. The total gold content is higher in sulfide minerals (11 ppm) than in pyrobitumen (7 ppm) (described below in detail). The total $\mathrm{Pt}$ value includes (490 ppb) appearing more in sulfide minerals than in pyrobitumen (31 ppb) while the $\mathrm{Pd}$ value found in pyrobitumen alone totals up to $26 \mathrm{ppb}$.

According to the ratio of gold to pyrobitumen and arsenic sulfide ore minerals in a triangular diagram (see below in Table 6 and Fig. 11), it can be seen that the gold content decreases from arsenopyrite (6 times more) and pyrobitumen (3times more) to pyrite in the nine samples from three groups. Samples show that the arsenopyrite mineral is more enriched in gold (on average, 56.15\%), especially in the samples from the second group, which corresponds to the main ore mineralization. Solid pyrobitumen comprises gold on average $33.38 \%$ of gold from three groups of samples, mainly from samples of the second group. The lowest content of gold (on average $6.27 \%$ ) is observed in pyrite, gold of pyrite includes mostly in the second group of samples. 
Table 7 Ratio of gold to organic carbon and arsenic element (from both arsenopyrite and pyrite) in nine samples

\begin{tabular}{|c|c|c|c|c|c|}
\hline \multirow[t]{2}{*}{ Sample groups } & \multirow[t]{2}{*}{ Sample labels } & \multicolumn{2}{|c|}{ Solid pyrobitumen and vitrinite } & \multicolumn{2}{|c|}{ Arsenic sulfide ores } \\
\hline & & $\begin{array}{l}\text { Gold } \\
\text { (unit, ppm) }\end{array}$ & $\begin{array}{l}\text { Organic carbon } \\
\text { (unit, \%) }\end{array}$ & $\begin{array}{l}\text { Gold } \\
\text { (unit, ppm) }\end{array}$ & $\begin{array}{l}\text { Arsenic } \\
\text { (unit, ppm) }\end{array}$ \\
\hline \multirow{3}{*}{ I } & Bak 2 & 2 & 0.34 & 0.6 & 986 \\
\hline & Bak 1 & 3 & 0.33 & 4.13 & 4050 \\
\hline & Bak 2,5 & 0.21 & 0.38 & 0.22 & 354 \\
\hline \multirow{3}{*}{ II } & Bak 2,3 & 0.19 & 0.47 & 0.89 & 3000 \\
\hline & Bak 2,2 & 0.22 & 0.43 & 1.31 & 3200 \\
\hline & Bak 2,1 & 0.76 & 0.32 & 2.23 & 3900 \\
\hline \multirow{3}{*}{ III } & Bol & 0.2 & - & 0.41 & 346 \\
\hline & Bak 2,4 & 0.44 & - & 0.53 & 2404 \\
\hline & Bak 2,25 & 0.21 & 0.31 & 0.53 & 367 \\
\hline
\end{tabular}

Fig. 12 Correlation of gold to the total organic carbon (TOC $\%)$ and arsenic element

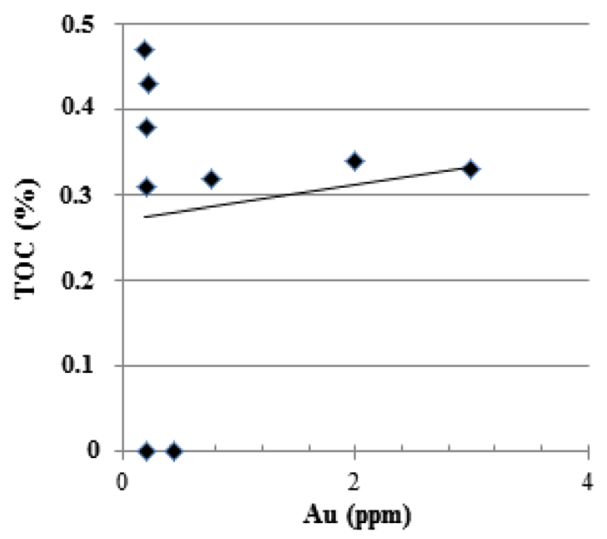

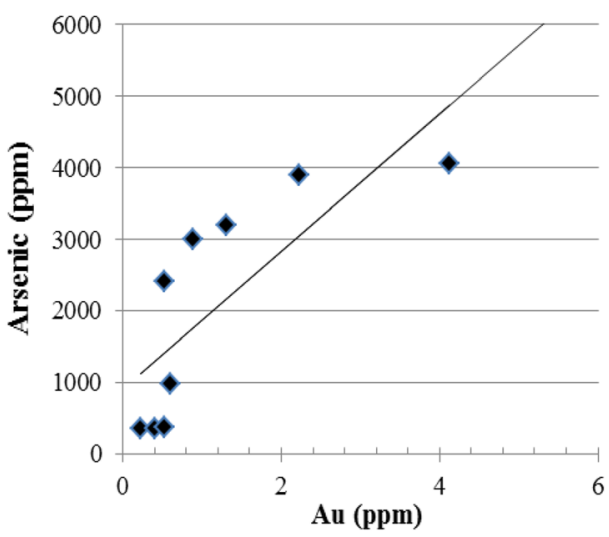

The results of the ratio of gold to the organic phase and ore sulfide phase indicate as a whole that the second group of samples from the main ore mineralization zone is more relevant and promising.

Correlation between gold and the total organic carbon (TOC) is found no correlation in nine samples, while gold with arsenic element is positively correlated in three sample groups (see below in Table 7 and Fig. 12). The reason for the lack of correlation between gold and TOC is more likely the weak thermal stability of some part of organic fractions in the hot hydrothermal system during polymerization. Other authors Rafailovich et al. (2011) confirm the positive correlation of gold with the arsenic element.

\section{Discussion}

\subsection{Source of organic matter (OM) and gold}

\subsubsection{Source of $O M$}

The bulk ratios of carbon isotope in organic matter $\left(\delta^{13} \mathrm{C}=-14 \div 31 \%\right.$ ) in the Bakyrchik deposit indicate its biogenetic nature and organic source (Zairi et al. 1987). Geochemical results, such as the presence of polycyclic (hetero) aromatic hydrocarbon and humic acid, indicate a terrestrial carbon source of lignin (TOC, $0.3-0.5 \%$ ) in the lacustrine environment, which has allochthonous nature due to gravity flows (Azerbaev and Zhautikov 2013).

The composition and source of kerogen in the sample (hardly distinguishable from pyrobitumen) partially confirms the terrestrial organic source, mainly from vascular plants, yielding an aromatic hydrocarbon (most likely the original coal source). The temperature of transformation of heating kerogen into liquid petroleum may occur at $231.3 \pm 30{ }^{\circ} \mathrm{C}$, which corresponds to its thermal maturity of $3.88 \%\left(\mathrm{RmcR}_{\mathrm{o}} \%\right)$.

\subsubsection{Source of gold}

Gold is of a mantle source and occurs in ultramafic rocks from the mantle to the oceanic basement (Rafaylovich 2009), which occurred $300 \mathrm{Ma}$ ago, spanning five geological ages: 574, 380, 300, 250, and $210 \mathrm{Ma}$ due to the isotopic analysis of $\mathrm{Pb}(\mathrm{Pb} / \mathrm{U}>50)$ in gold-bearing sulfide minerals (Lubecky et al. 2008; Umarbekova and Dyusembaeva 2019). The first gold occurrence (574 Ma) is 
related to the riftogenic stage of the Late Cambrian and Early Ordovician $\left(\epsilon_{3}-\mathrm{O}_{1}\right)$, the second mineralization ( $380 \mathrm{Ma}$ ) is associated with the oceanic stage of the Early Devonian and Middle Devonian $\left(\mathrm{D}_{1-2}\right)$ with regression of the palaeo-ocean and formation of the volcanic island-arc stage in Late Devonian and Early Carboniferous $\left(\mathrm{D}_{3} \mathrm{fm}-\right.$ $\left.\mathrm{C}_{1} \mathrm{v}\right)$ above the subduction zone associated with basaltandesitic complexes. The age of $300 \mathrm{Ma}$ is related to an early collision with the intrusion of the Kunush goldbearing intrusive complex at the Late Carboniferous and Late Permian age $\left(\mathrm{C}_{3}-\mathrm{P}_{1}\right)$; it is a great granitic batholith and the source of the main gold generation. The final stage of gold occurrence ended between 250 and $210 \mathrm{Ma}$, the Middle Triassic and Late Triassic age $\left(\mathrm{T}_{2-3}\right)$, characterized by regeneration of gold (Lubecky et al. 2008).

\subsection{Mobilization and preservation of $\mathrm{OM}$ and gold}

\subsubsection{Maturation, migration, and entrapment of OM}

Vitrinite at the anthracite stage shows that migration went on at $235.5 \pm 30{ }^{\circ} \mathrm{C}$ confirmed with thermal maturity of $3.76 \%\left(R m c R_{o}\right)$. This bituminous matter and, partially, vitrinite is most likely migrated by a hydrothermal system as angular-shaped forms from the high-temperature zone to the low-temperature zone through large voids in the host rock. The large void filling of reworked vitrinite displays medium to coarse-grain mosaic textures of particle assemblages in samples of Bak 1, Bak 2.1, and Bak 2.5.

The reworked vitrinite coexisted within framboidal and needle-shaped digenetic pyrite. The coexistence of framboidal sphalerite in the reworked vitrinite grains is also attributed to a diagenetic, epigenetic origin. The framboidal and needle-shaped textures of sulfide crystals have been observed growing from metal-enriched $\mathrm{H}_{2} \mathrm{~S}$-bearing hydrothermal fluids, according to the concept of Scott et al. (2009) in a gold sulfide deposit. The needle-shaped pyrite and framboidal pyrite and sphalerite of reworked vitrinite include minor elements $\mathrm{As}, \mathrm{Sb}, \mathrm{Zn} \mathrm{Cu}$, and $\mathrm{Ni}$ (from pyrite), and $\mathrm{P}$ (from sphalerite), while the reworked vitrinite enriched in $\mathrm{S}, \mathrm{Cl}$ and $\mathrm{P}$.

Reworked vitrinite and other vitrinite particles contain 90 wt.\% carbon, and 2 wt.\% organic sulfur and other elements $(\mathrm{P}$ and $\mathrm{Cl})$ preserved as sulfur-rich reworked vitrinite. Dai et al. (2015) indicated that organic sulfur is generated from hydrothermal solutions during the coalification stage, ranging from about $0.1 \%$ to $4-12 \%$ levels (Dai et al. 2020). Organic sulfur is more abundant in bituminous coal and anthracite than in low-rank coals as thiophenic sulfur compounds (Chou 2012). The content of thiophenic sulfur increases with maturation (Ho et al. 1974) in bitumen with a high content of aromatic hydrocarbons, resins, and asphaltenes (Tissot and Welte 1984), thermostable up to $250{ }^{\circ} \mathrm{C}$ in hydrothermal fluids (Giordano 2000). Hwang (1998) indicated that the formation of sulfur-rich pyrobitumen is a result of subsequent thermal change in asphaltic-rich bitumen in the presence of sulfur species. Moreover, Powell (1984) confirmed that the interaction of bitumen with the thermochemical reduction of sulfate should be responsible for the formation of some sulfur-rich bitumens.

Chlorine is present in organic matter, as Caswell et al. (1984a, b) described that chlorine is more likely taken from Cl-rich groundwater during diagenesis. Chou et al. (1992) found that, under reducing conditions, chlorine, in the form of $\mathrm{HCl}$, is released at temperatures between 250 and $600{ }^{\circ} \mathrm{C}$, with a maximum release at $445^{\circ} \mathrm{C}$. Finkelman (1981) and Black (1981) believed that phosphorus in most organic matters is likely to be present in phosphates, where phosphorus is organic rather than a mineral fraction.

Pyrobitumen of the first type (PB2) migrates at a temperature of $254{ }^{\circ} \mathrm{C}$, and its thermal maturity is $3.94 \%$ $\left(R m c R_{o}\right)$. It migrates through very narrow fractures and voids within hydrothermal quartz in the host rock and is retained as tiny narrow-filling forms within the hydrothermal quartz, showing a quite weak fluorescence intensity. The occurrence of a thin membrane adhered to the wall rocks may explain that the bitumen precipitated as an immiscible phase with the hydrothermal fluid and slowly flowed along the wall of veins due to its consistent transformation into this type of pyrobitumen.

The second type of pyrobitumen (PB3) migrated at a relatively higher temperature of $276.9 \pm 30^{\circ} \mathrm{C}$, with thermal maturity of $3.97 \%\left(R m c R_{o}\right)$, and it migrated withwT the hydrothermal fluid to the low-temperature zone through narrow fissures; it is entrapped in the relatively narrow voids of the hydrothermal quartz.

The two sizes of veins of pyrobitumens on quartz may explain that they were displaced and trapped within a different chemical composition during the distillation process, as cooling the hydrothermal fluid can cause differentiation in the chemical composition of the bitumen. The final freezing point of the mixture and the molecule size, which can migrate through the neck diameter, controls this process.

Solid pyrobitumen and vitrinite are polymerizing to increase aromatic compounds and losing aliphatic hydrocarbon during the migration within the hot hydrothermal fluid. This aromatic hydrocarbon-enriched bitumen is trapped with decreasing the fluid temperature in quartz in the lower temperature zone, as a filler in voids of the quartz matrix. Thus, the heavy component of the bitumen is trapped within hydrothermal quartz, pyrolyzed and converted to pyrobitumen as a result of thermally altered primary bitumen, which was driven off the soluble hydrocarbon products and volatile organic components of 
$\mathrm{N}, \mathrm{H}, \mathrm{CH}_{4} \mathrm{CO}_{2}$ (Zairi et al. 1987), retained in the insoluble carbon-rich residues. The carbon isotope of the solid pyrobitumen and vitrinite $\left(\delta^{13} \mathrm{C}=-22 \div 26,8 \%\right.$ o $)$ confirms that it has a terrigenous origin (Zairi et al. 1987).

\subsubsection{Transport and precipitation of gold}

Rafailovich (2009) has considered transportation and precipitation of gold in the deposit by three processes (1) In the sedimentary-diagenetic process, gold was transported by a bisulfide gold and depositing in the shallow zone and underwater deltas, rich in organic matter and hydrogen sulfide, framboidal pyrite precipitated on rhythmically layered gold-bearing carbonaceous sediments. (2) In the tectonic-metasomatic process, gold was transported in a mineralized solution as a chloric complex of gold and precipitated in carbonaceous-terrigenous sediments, while framboidal pyrite recrystallized into gold-bearing pyrite of cubic and pentagon-dodecahedral forms with inclusions of arsenic. (3) In the intrusive-thermal-metasomatic process, syngenetic gold was remobilized along the Qyzyl shear zone in the areas of intrusions and dikes of the Kunush granitic complex, and then gold reached the final precipitations with pyrobitumen.

\subsection{Role of solid pyrobitumen in the Bakyrchik gold deposit}

\subsubsection{OM and gold mineralization}

The gold mineralization of the deposit occurs in the Qyzyl shear zone (Lubecky et al. 2008). Zhu et al. (2011) considered that the gold mineralization in most shear zones is a result of post-peak metamorphism and associates a multistage alteration event.

Current and previous analytical and experimental data may explain the role of pyrobitumen in the Bakyrchik gold deposit by separating the three geological processes of gold mineralization, which, most likely, correspond to regional maturations of the three pyrobitumen types:

1. Syngenetic gold accumulates in the sedimentary-diagenetic process with an increasing precursor asphalticrich hydrocarbon at low temperature in a slightly alkaline environment with the penetration of hydrogen sulfide-rich hydrothermal fluids into clay or silty lacustrine sediments of the Middle-Late Carboniferous formation. The bisulfide gold is transported a hydrothermal fluid and the fluid mobilizes asphalticrich bituminous materials through large voids of mineral grains of the host rock in the high-temperature zone. Simoneit (2018) mentioned that a hydrothermal ore fluid can rapidly generate bituminous material

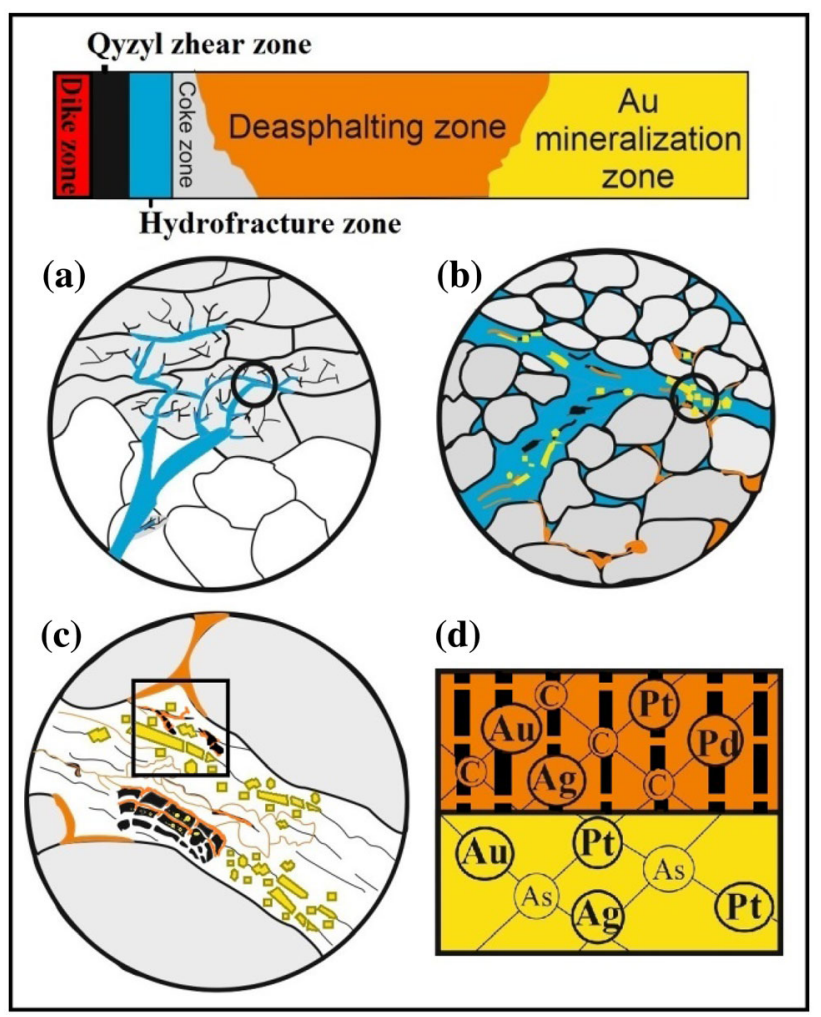

Fig. 13 Schematic model of the formation of gold compounds of organic matter and arsenic sulfide ore minerals in six active zones of the Bakyrchik gold deposit showing a penetration of the hot hydrothermal ore fluid (blue) into liquid bituminous materials (in coke zone, grey) through fissures and fractures in the host rock (white); b migration of gold, bitumen (orange) and sulfide ore components (yellow) into the hydrothermal fluid; c entrapment of gold, bitumen, and ore elements undergoing thermal and chemical influences for gold precipitation (in $\mathrm{OM}$ and ore minerals), and bitumen maturation (origin of $(\mathrm{V})$ reworked vitrinite (black) and its thermochemical reduction for framboidal pyrite, and two veined pyrobitumens (PB1, PB2) with increasing thermal maturation and arsenic sulfide minerals occurrence (arsenian pyrite and arsenopyrite); d gold inclusions in polycyclic aromatic hydrocarbons of pyrobitumens (orange) and vitrinite (black) as metal-organic compounds (noble metals) and "invisible gold" in the arsenic structure lattice of arsenian pyrite and arsenopyrite (yellow). Detail view at the micron size (a-c) and nano-size (d). (complied by CorelDRAW Graphics Suite X6)

from immature organic matter to fully matured products in host rocks. Ore fluid destroys only partly the organic matter with an increase of aromatic hydrocarbon content (polycyclic compound) and loss of aliphatic carbon content because the thermogenic products are rapidly removed from the hot zone through voids (Simoneit 1994). The low-temperature hydrothermal water may contribute to the thermochemical origin of framboidal pyrites in asphaltic-rich carbonaceous materials, where the palaeotemperature was up to $235 \pm 30{ }^{\circ} \mathrm{C}$ shown by the thermal maturation of reworked vitrinite $(\mathrm{V})$. 
2. The tectonic-metasomatic process has resulted in the Qyzyl deep fault zone of $2 \mathrm{~km}$ length in the diagonal direction, which is the controlling structure of gold mineralization in the carbonaceous-siltstone sequence. Gold is transported in a chloric state phase into the hydrothermal fluid with the presence of liquid bituminous material. The first arsenian pyrite with invisible gold content develops with the recrystallization of framboidal pyrite Rafaylovich et al. (2009). The bituminous material is removed from the high-temperature alteration of texture filling very thin voids of mineral grains of the host rock at a temperature of $254 \pm 30^{\circ} \mathrm{C}$, forming very thin veined solid piyrobitumen (PB1). The occurrence of bitumen in thin veins may be explained by the fact that bitumen is transported as an immiscible phase with the oreforming fluid.

3. In the intrusive-thermal-metasomatic process, we are concerned with intrusions and dikes from the Kunush granitic complex at a depth of $4 \mathrm{~km}$ (Lubecky et al. 2008) along the Qyzyl shear zone and the main gold mineralization belongs to sulfide ore zones. Gold mineralization of the deposit occurs in sulfide ore zones with the presence of carbonaceous matter. The Qyzyl fault zone was the single place where gold and pyrobitumen were concentrated in arsenic-sulfide minerals accompanied with ore-forming hydrothermal fluid upwards through the fault (see in Fig. 13).

Studies of fluid-inclusions of quartz from the ore zone showed that the main gold mineralization zone takes place at $340{ }^{\circ} \mathrm{C}$ and a pressure of $110-130 \mathrm{MPa}$ with the formation of invisible gold-bearing arsenic sulfide minerals and by a decrease in temperature to $200{ }^{\circ} \mathrm{C}$ in gold mineralization with the appearance of antimony minerals (Novojilov and Gavrilov 1999). Pyrite and arsenopyrite predominate in the ore zone, while chalcopyrite and galena formed less frequently Umarbekova et al. (2017a) in relatively deep ones (Levitan 2008). Pyrite occurs in invisible gold-containing cubic pyrite and high gold-containing pentagon-dodecahedral forms in the circumstances of high temperature (Rafaylovich et al. 2011). In the upper zone, arsenian pyrite predominates the arsenopyrite in the ratio of $3.5: 1$, while in the middle and lower zones, more arsenopyrite occurs with a ratio is of 1:3 (Rafaylovich et al. 2011). High $\mathrm{Au}$ concentration positively correlated with As-rich compositions in pyrite and arsenopyrite minerals Rafaylovich et al. (2011). The content of As element is $0.005-0.6 \%$ and the As in pyrite ranges from 1 to $1.5 \%$ Rafaylovich et al. (2011). Stibnite and valentinite are associated with native antimony Levitan (2008). The antimony content increases towards the near-surface area, and decreases in the deep zone (between 0.2 and $0.3 \%$ )
(Volkov and Sidorov 2017). Nevertheless, the isotopic composition of the antimony sulfur showing close values within the $\delta^{34} \mathrm{~S}$ of the interval from -3.8 to $2.5 \%$ (Kovalev et al. 2014).

The sulfide ore minerals have a magmatic source: the $\mathrm{S}$ isotope analysis in sulfide ore minerals shows that $\delta^{34} \mathrm{~S}$ belongs to the felsic magmatic origin, the $\mathrm{S}$ becomes heavier with the increase in its depth from $-4 \ldots-6 \%$ in the depth of $0.5 \mathrm{~km}$ to $0.0 \%$ in the depth of $1.5 \mathrm{~km}$ (Rafaylovich et al. 2011).

Simon et al. (1999) explained that Au and As are closely related in arsenian pyrite and arsenopyrite with a linear relationship: $C_{\mathrm{Au}}=0.02 C_{\mathrm{As}}+4 \times 10^{-5}\left(C_{\mathrm{Au}}\right.$ and $C_{\mathrm{As}}$ represent the mole percentage of $\mathrm{Au}$ and $\mathrm{As}$ concentration, respectively). As-bearing pyrite shows that the solid solution of gold has two coordination species: $\mathrm{Au}^{\circ}$ and $\mathrm{Au}^{+}$ (Simon et al. 1999). $\mathrm{Au}^{+}$can occur in more than one form, including $\mathrm{Au}^{+}$in vacancies in an unknown Au-As-S complex (Simon et al. 1999). Gold occurs in arsenic sulfide minerals as a solid solution and nano-inclusions in oversaturated conditions (Reich et al. 2005). Solid solution gold $\left(\mathrm{Au}^{+}\right)$enters As-bearing pyrite and arsenopyrite by replacing $\mathrm{Fe}^{2+}$ (Tarnocai et al. 1997) extracts of the solid solution of $\mathrm{Au}^{+}$from the hydrothermal fluid by absorption (Zhu et al. 2011).

Bitumen in the hydrothermal vein system can be enriched with the same metals that form ore minerals in the system (Parnell 1988). The homogenization temperature of gold mineralization is $270{ }^{\circ} \mathrm{C}$ on average (from 200 to $340{ }^{\circ} \mathrm{C}$ ) (Novojilov and Gavrilov 1999), which corresponds to the thermal maturation of narrow veined pyrobitumen (PB2). The carbonaceous materials are formed everywhere in the ore zones and have maximum in the central part of the main ore zone (Rafaylovich et al. 2011). As Saxby (1976) revealed, organic matter and metals dissolved in the hydrothermal fluid can be concentrated and precipitated by a reaction with suitable organic ligands as chemisorption into organic materials forming metal-organic compounds. Metal-complexing functional groups form in heterocyclic hydrocarbons containing nitrogen and sulfur (Saxby 1976), concentrating mostly in the asphaltene fraction of bitumen (Giordano 2000).

\subsubsection{Preliminary roles of $O M$ in the formation of "invisible gold" in sulfide minerals}

Gold was detected from the soluble part (in the hydrogen peroxide) of polycyclic aromatic fractions in pyrobitumen as a metal-organic compound and in arsenic sulfides (dissolved by the hydro ammonium chloride and aqua regia) as inclusions of "invisible gold". The experiment shows no correlation between gold and organic carbon $\left(\mathrm{C}_{\text {org }}\right)$, while the arsenic content correlates positively with 
gold. In this case, there are two most likely reasons, why it happens during the migration. First, the precursor of liquid bitumen undergoes in the three different regional thermal influences, in which gold of the functional groups in bitumen is partly removed due to the thermally stable and preserved different gold content in different thermal zones. Secondly, the bitumen of gold complexes in the fluid migrates in a different direction through various voids lingering there due to molecular sizes of bitumen with different gold contents. Maybe this is one of the reasons when gold is partially removed from non-thermostable functional groups of bitumen in the hydrothermal system and then the removed gold precipitates most likely in the structure of arsenic sulfide minerals.

Other authors indicate this too; Saxby (1976) revealed that reduction of soluble $\mathrm{Au}^{1+}$ or $\mathrm{Au}^{3+}$ complexes to $\mathrm{Au}^{\mathrm{O}}$ by carbonaceous materials may account for some types of gold mineralization.

Jiuiling et al. (1997) explained that organic compounds of gold have a strong ability to migrate with As and $\mathrm{S}$ upward together with metal-organic compounds. Organic matter containing gold in hydrothermal ore fluid is thermally decomposed, removing gold from its organic ligand, and gold together with the arsenic element enters into the lattice of arsenopyrite and arsenian pyrite (Jiuiling 1997). Gold can form many types of compounds with organic ligands, especially those metal-organic compounds and atom cluster compounds containing $\mathrm{S}, \mathrm{P}$, and $\mathrm{Cl}$ (Jiuiling 1997).

This explains that the precursor of liquid bitumen in the hydrothermal ore fluid mobilizes gold as metal-organic compounds and, as a part of the organic fraction of gold, undergoes thermal decomposition, releasing dissolved gold and the rest of the preserved organic fraction that forms gold. When removed from organic matter, gold is chemically bound in the structures of arsenopyrite and arsenian pyrite forming invisible gold. The remaining gold in organic functional groups forms gold-containing solid pyrobitumen as metal-organic compounds.

\section{Conclusion}

According to the research data, we can suggest that the occurrence of pyrobitumen in the nine studied samples and their role in the gold mineralization are based on the following observational evidence: (1) The OM precipitated in the form of pyrobitumen and occurred as migrated reworked vitrinite, inherent primary vitrinite, and inertinite particles. (2) The samples contain inherent primary and secondary organic matter. (3) Enrichments of gold were confirmed in this study in the fracture zones formed by hydrothermal sulfide mineralization in the form of arsenopyrite and arsenian pyrite. (4) OM was active in the migration of gold and the capture of gold in the heteroaromatic fractions of pyrobitumen. OM could in one way absorb gold and precipitate as a metal-organic complex into the small veins and voids, in which the throat diameter of fractures and voids was smaller than the size of the molecule. (5) OM was transformed into pyrobitumen, retaining some of the gold in thermally stable organic fractions and liberating some of the gold from thermally unstable compounds of organic fractions. The thermally unstable $\mathrm{OM}$ was reduced during oxidation by the hydrothermal system, removing and forming dissolved gold particles for further sulfide mineralization. (6) The reductive OM agent liberated gold into arsenic lattice structure sulfide ore minerals with an arsenic lattice structure in the fracture zone. (7) Apparently, pyrobitumen may indicate that it was a critical agent in the concentrations, transport, and storage of the gold in the deposit.

The content of solid pyrobitumen in the Bakyrchik gold deposit varies around 24 million tons (Mizernaya 2001). This shows that pyrobitumen is also more attractive for improving understandings of the origin, transport, and storage of gold with organic matter, which will help to develop more reliable exploration programs for the bitumen-ore association in the deposit.

Acknowledgements The research was carried out within the framework of the "Improved exploitation and utilization of subsurface natural resources" (TUDFO/51757-1/2019-ITM) Thematic Excellence Program of the University of Miskolc, financed by the National Research, Development and Innovation Office of Hungary. Moreover, the work was carried out as part of the Sustainable Raw Materials Management Thematic Network-RING 2017, EFOP-3.6.2-201700010 project in the framework of the Széchenyi 2020 Program. The implementation of this project is supported by the European Union, co-financed by the European Social Fund. Furthermore, this research work was completed as a part of a Ph.D. dissertation at the University of Miskolc. Special thanks to my supervisors M. Ferenc and V. Mária for their comments and discussion in improving the quality and coauthors for their analytical measurements. Many thanks to D. Debus; F. Móricz, J. Richards, and M. Leskó for helps with laboratory experiments that contributed to the submission of this paper.

Funding Open access funding provided by University of Miskolc. "Improved exploitation and utilization of subsurface natural resources" (TUDFO/51757-1/2019-ITM) Thematic Excellence Program of the University of Miskolc, financed by the National Research, Development and Innovation Office of Hungary. Sustainable Raw Materials Management Thematic Network-RING 2017, EFOP3.6.2-2017-00010 project in the framework of the Széchenyi 2020 Program. The implementation of this project is supported by the European Union, co-financed by the European Social Fund.

\section{Declarations}

Conflict of interest The authors declare that they have no known competing financial interests or personal relationships that could have appeared to influence the work reported in this paper. 
Open Access This article is licensed under a Creative Commons Attribution 4.0 International License, which permits use, sharing, adaptation, distribution and reproduction in any medium or format, as long as you give appropriate credit to the original author(s) and the source, provide a link to the Creative Commons licence, and indicate if changes were made. The images or other third party material in this article are included in the article's Creative Commons licence, unless indicated otherwise in a credit line to the material. If material is not included in the article's Creative Commons licence and your intended use is not permitted by statutory regulation or exceeds the permitted use, you will need to obtain permission directly from the copyright holder. To view a copy of this licence, visit http://creativecommons. org/licenses/by/4.0/.

\section{References}

Azerbaev NA, Zhautikov TM (2013) Lithology of carbonaceousterrigenous complexes in the Bakyrchik strata. VII Russian Lithological Congress 28-31 October 2013. Novosibirsk (in Russian)

Baskakova MP (1970) Organic matter in gold-ore quartz veins in the Kyzyl-Kum sands. Dokl Akad Nauk Uzb SSR 27(12):30-32 ((in Russian))

Beckett PH (1989) The use of extractants in studies on trace metals in soils sewage sludges and sludge-treated soils. Adv Soil Sci 9:143-176

Belin S (1994) Backscattered electron imaging applied to source rock sedimentology: a comparison with conventional methods in organic petrology. Bull Des Centres De Recherches Explor Prod 18:165-187

Black PM (1981) Taranaki coalfields: coal quality. NZ Energy Res Dev Comm Publ No. P5:25

Boyle RW (1979) The geochemistry of gold and its deposits. Geol Surv Can Bull 280:584

Bürg GH (1930) Die Sichtbarmachung des feinverteilten Goldes in goldhöffigen Erzen und ihre wirtschaftliche Bedeutung. Metall u Erz 27:333-338

Cabri LJ, Chryssoulis SL, de Villiers JPR, Laflamme JHG, Bruseck PR (1989) The nature of "invisible" gold in arsenopyrite. Can Miner 27:252-362

Cardott BJ, Ruble TE, Suneson NH (2007) Nature of migrabiturnen and their relation to regional thermal maturity Ouachita Mountains Oklahoma. Energy Sources 15:239-267. https://doi.org/10. 1080/00908319308909026

Caswell SA, Holmes IF, Spears DA (1984a) Total chlorine in coal seam profiles from the South Staffordshire (Cannock) coalfield. Fuel 63:782-787

Caswell SA, Holmes IF, Spears DA (1984b) Water-soluble chlorine and associated major cations from the coal and mudrocks of the Cannock and North Staffordshire coalfields. Fuel 63:774-781

Chou CL (2012) Sulfur in coals: a review of geochemistry and origins. Int J Coal Geol 100:1-13

Chou CL, Hackley KC, Donnals GL, Cao J, Ruch RR (1992) Evolution of hydrogen chloride during temperature-programmed pyrolysis of Illinois coal. Geol Soc Am Prog Abstr 24:202

Cook NJ, Chryssoulis SL (1990) Concentrations of "invisible gold" in common sulfides. Can Miner 28:1-16

Crocket JH (1991) Distribution of gold in the Earth's crust. In: Foster RP (ed) Gold metallogeny and exploration. Chapman and Hall, London, pp 1-36

Dai Sh, Seredin VV, Ward CR, Hower JC, Xing Y, Zhang W, Song W, Wang P (2015) Enrichment of U-Se-Mo-Re-V in coals preserved within marine carbonate successions: geochemical and mineralogical data from the Late Permian Guiding Coalfield Guizhou China. Miner Depos 50:159-186

Dai S, James C, Hower R, Finkelman T, Graham D, Colin R, Warde G, Qiang W, Lei Zh (2020) Organic associations of non-mineral elements in coal: a review. J Coal Geol 218:103347

Davidson CM, Ferreira PS, Ure AM (1999) Some sources of variability in application of the three-stage sequential extraction procedure recommended by $\mathrm{BCR}$ to industrially-contaminated soil. Fresenius' J Anal Chem 363:446-451

Dold B, Fontboté L (2001) Element cycling and secondary mineralogy in porphyry copper tailings as a function of climate primary mineralogy and mineral processing. Geochem Explor 74:3-55

Dyachkov B, Mizernaya M, Kuzmina O, Zimanovskaya N, Oitseva T (2017) Tectonics and metallogeny of East Kazakhstan. Intechopen. https://doi.org/10.5772/intechopen72745

Dyachkov BA, Mizernaya MA, Maiorova N, Chernenko Z, Maiorov V, Kuzmina O (2011) Geotectonic position and metallogeny of the greater altai geological structures in the system of the central Asian mobile belt. New Frontiers in Tectonic Research - General Problems Sedimentary Basins and Island Arcs

Emsbo P, Koenig A (2007) Transport of Au in petroleum: evidence from the northern Carlin Trend Nevada. In: Digging Deeper Biennial SGA Meeting 9th Dublin Society for Geology Applied to Mineral Deposits Proceedings, pp 695-698

Farfel' LS (1980) The role of organic matter and ground water in hydrothermal sulfide formation. Byul Mosk Obshch Ispyt Prirody Otd Geol 55:114-122 (in Russian)

Farfel' LS, Savel'yeva NI, Mironov AO (1984) Hydrothermal solutions at the Aksu gold-ore deposit. Geochem Int 21:71-76

Finkelman RB (1981) Modes of occurrence of trace elements in coal. US Geol Surv Open-File Rep No OFR-81-99: 301 also PhD Thesis University of Maryland 1980

Fleet ME, Chryssoulis SL, MacLean PJ, Davidson R, Weisener CG (1993) Arsenian pyrite from gold deposits; Au and As distribution investigated by SIMS and EMP and color staining and surface oxidation by XPS and LIMS. Can Miner 31:1-17

Fuchs S, Anthony E, Williams-Jones S, Jackson E (2016) Metal distribution in pyrobitumen of the Carbon Leader Reef Witwatersrand Supergroup South Africa: evidence for liquid hydrocarbon ore fluids. Chem Geol. https://doi.org/10.1016/ jchemgeo201602001

Fuxin Z, Jianqin M, Yanjing C (2001) Geochemical study of gold and arsenic mineralization of the Carlin-Type gold deposits Qinling region China. Chin J Geochem 20(4):1-10

Gatellier J, Disnar J (1989) Organic matter and gold-ore association in a hydrothermal deposit, France. J Appl Geochem 4:143-149

Giordano TH (1994) Metal transport in ore fluids by organic ligand complexation. In: Pitman ED, Lewan MD (eds) Organic acids in geological processes. Springer, New York, pp 319-354

Giordano TH, Kharaka YK (1994) Organic ligand distribution and speciation in sedimentary basin brines diagenetic fluids and related ore solutions. In: Parnell J (ed) 1994 Geofluids: origin migration and evolution of fluids in sedimentary basins 175 . Geological Society Special Publication No 78: 175-202

Giordano TH (2000) Organic matter as a transport agent in oreforming systems. In: Giordano TH, Kettler RM, Wood SA (eds) Ore genesis and exploration: the roles of organic matter reviews. Econ Geol Vol 9: 133-155

Glikson M, Golding SD, Boreham CJ, Saxby JD (2000) Mineralization in eastern Australia coals: a function of oil generation and primary migration. In: Glikson M, Mastalerz M (eds) Organic matter and mineralisation. Kluwer Academic Publishers, New York, pp 314-326 
Goldfarb RJ, Taylor RD, Collins GS, Goryachev NA, Orlandini OF (2014) Phanerozoic continental growth and gold metallogeny of Asia. Gondwana Res 25:48-102

Hanping Z, Jialan L, Jiamo F, Chigang R, Degang Z (1999) Crude oil as carrier of gold: petrological and geochemical evidence from Lannigou gold deposit in southwestern Guizhou China. Sci China Ser D Earth Sci 42:216-224

Ho TY, Rogers MA, Drushel HV, Koons CB (1974) Evolution of sulfur compounds in crude oils. Am Assoc Pet Geol Bull 58:2338-2348

Huc A, Nederlof P, Debarre R, Carpentier B, Boussafir M, LaggounDéfarge F, Lenail-Chouteau A, Bordas-Le Floch N (2000) Pyrobitumen occurrence and formation in a Cambro-Ordovician sandstone reservoir Fahud Salt Basin North Oman. Chem Geol 168:99-112

Hunt JM (1978) Characterization of bitumens and coals. Bull Am Assoc Pet Geol 62:301-303

Hwang RJ, Terrman SC, Carlson RM (1998) Geochemical comparison of reservoir solid bitumens with diverse origins. Ors Geochem 29(1-3):505-517

Jacob H (1985) Disperse solid bitumens as an indicator for migration and maturity in prospecting for oil and gas. Erdol Und KohleErdgas 38:365

Jacob H (1989) Classification structure genesis and practical importance of natural solid bitumen ("migrabitumen"). Int J Coal Geol 11:65-79

Jehlicka J, Urban O, Pokorný J (2003) Raman spectroscopy of carbon and solid bitumens in sedimentary and metamorphic rocks. Spectrochimica Acta Part A 59:2341-2352

Jiuling L, Feng Q, Quingsheng X (1997) The role of organic and carbonaceous matter in the formation of Carlin-type disseminated gold deposits. In: Pei R (ed) Proceedings of the 30th international geology congress, vol 9, pp 337-354. VSP 1997

Kouketsu Y, Mizukami T, Mori H, Endo S, Aoya M, Hara H, Nakamura D, Wallis S (2014) A new approach to develop the Raman carbonaceous material geothermometer for low-grade metamorphism using peak width. Island Arc 23:33-50

Kovalev KR, Kalinin YuA, Naumov EA, Myagkaya MK (2014) Relationship of antimony with gold mineralization in the ore districts of Eastern Kazakhstan. Russ Geol Geophys 55:1170-1182

Large RR, Maslennikov VV (2020) Invisible gold paragenesis and geochemistry in pyrite from orogenic and sediment-hosted gold deposits. Minerals 10(339):1-21. https://doi.org/10.3390/ $\min 10040339$

Levitan G (2008) Gold deposits of the CIS. USA: Xlibris Corporation

Liang L, Jian-Ming Z (2016) An optimized sequential extraction scheme for molybdenum association in environmental samples. Acta Geochim 35(2):111-119. https://doi.org/10.1007/s11631016-0096-4

Liu DH, Xiao XM, Tian H, Min YSh, Zhou Q, Cheng P, Shen JG (2013) Sample maturation calculated using Raman spectroscopic parameters for solid organics: methodology and geological applications. Chin Sci Bull 58(11):1285-1298

Lubecky VN, Bespaev HA, Libeckay LD (2008) The deep model of fold deposits of Bakyrchik and Vasylkovskoe. IGS Named KI Satpaev 1:25-36 (in Russian)

Marchenko LG, Komashko LV (2011) The role of nanostructured particles and carbon films in accumulation of precious metals on deposits "balck shale" type. Izvestiya NAN RK Sergeologicheskaya 5:6-85 (in Russian)

Marchenko LG (2010) Micro and nano-mineralogy of gold in a black shale formation. Almaty ISBN 978-601-278-228-8: 2-138 (in Russian)

Merwin RW (1968) Gold resources in the oxidized ores and carbonaceous material in the sedimentary beds of northeastern Nevada. US Bur Mines Tech Progress Rep
Migdisov AA, Guo X, Xu H, Williams-Jones AE, Sun CJ, Vasyukova O, Sugiyama I, Fuchs S, Pearce K, Roback R (2017) Hydrocarbons as ore fluids. Geochem Perspect Lett 5:47-52. https://doi. org/10.7185/geochemlet 1745

Milner CW, Rogers MA, Evans CR (1977) Petroleum transformations in reservoirs. J Geochem Explor 7:101-153

Mizernaya MA (2001) Location of shungite in black shale formation of West Qalba. Herald VKGTU 1:32-40 (in Russian)

Narseev VA, Gostev YuV, Zaharov AV (2001) Bakyrchik (geologiya geohimiya orudinenie). Moskva 174

Novojilov YuI, Gavrilov AM (1999) Gold-sulfide deposits in carbonaceous-terrigenous formations. CNIGRI, Moscow

Osovetsky B (2017) Natural nanogold ISSN 2366-1593 (electronic). Springer Mineralogy ISBN 978-3-319-59158-2: 91-97

Parnell J (1988) Metal enrichments in solid bitumens: a review. Miner Deposita 23:191-199

Parnell J (2019) Variscan cycling of gold into a global coal reservoir. Ore Geol Rev 114(103158):1-7

Parnell J, McCready A (2000) Paragenesis of gold- and hydrocarbonbearing fluids in gold deposits. In: Glikson M, Mastalerz M (eds) Organic matter and mineralisation. Kluwer Academic Publishers, New York, pp 38-52

Powell TG (1984) Some aspects of the hydrocarbon geochemistry of a Middle Devonian barrie-reef complex Western Canada. In: Palacas JG (ed) Petroleum geochemistry and source rock potential of carbonate rocks. American Association Petroleum Geologists Studies in Geology 18: 45-62

Radtke AS, Scheiner BJ (1970) Studies of hydrothermal gold deposition 1 Carlin Gold Deposit Nevada: the role of carbonaceous materials in gold deposition. Econ Geol 65:87-102

Rafaylovich MS (2009) The large gold-sulphide deposit of Bakyrchik in Kazakhstan: geological structure prospecting model. Geol Miner Resour 4:31-38

Rafaylovich MS, Myzernaya MA, D'yachkov BA (2011) The gold deposits in the black shale formations: condition of origin similarity. Almaty 55-76

Razvozzhaeva EA, Prokof'ev VY, Spiridonov AM, Martikhaev DK, Prokopchuk SI (2002) Precious metals and carbonaceous substances in ores of the Sukhoi Log deposit eastern Siberia Russia. Geol Ore Depos 44:103-111

Reich M, Kesler SE, Utsunomiya S (2005) Solubility of gold in arsenian pyrite. Geochim Cosmochim Acta 69:2781-2796

Rogers MA, McAlary JD, Bailey NJ (1974) Significance of reservoir bitumens to thermal-maturation studies West Canada Basin. Bull Am Assoc Pet Geol 58:1806-1824

Romberger SB (1988) Geochemistry of gold in hydrothermal deposits. US Geol Surv Bull 1857-A:A9-A25

Ross RL, Stuart WB, Valeriy VM (2011) Carbonaceous sedimentary source-rock model for carlin-type and orogenic gold deposits. Econ Geol 106:331-358

Saxby JD (1976) The significance of organic matter in ore genesis. In: Wolf KH (ed) Strata-bound and stratiform ore deposits, 2nd edn. Elsevier, Amsterdam, pp 111-134

Scott RJ, Meffre J, Woodhead SE, Gilbert RF, Berry PE (2009) Development of framboidal pyrite during diagenesis low-grade regional metamorphism and hydrothermal alteration. Econ Geol 104(8):1143-1168. https://doi.org/10.2113/gsecongeo10481143

Seitmuratova EY, Goganova LA, Lyapichev GF, Radchenko MI, Marfenkova MM (1997) Stratigraphy of the Carboniferous and Permian of Kazakhstan Proceedings of the Xlll International congress on the Carboniferous and Permian/ Warshawa

Simon G, Kesler SE, Chryssoulis S (1999) Geochemistry and textures of gold-bearing arsenian pyrite Twin Creeks Nevada: implications for deposition of gold in Carlin-type deposits. Econ Geol 94:405-422 
Simoneit BRT (2000) Alteration and migration processes of organic matter in hydrothermal systems and implications for metallogenesis. In: Glikson M, Mastalerz M (eds) Organic matter and mineralization: thermal alteration hydrocarbon generation and role in metallogenesis. Kluwer Academic Publishers, Dordrecht, pp 13-37

Simoneit BRT (1994) Lipid/bitumen maturation by hydrothermal activity in sediments of Middle Valley Leg 139. In: Mottl M, David E, Fisher A, Slack J (eds) Proceedings of the ocean drilling program scientific results, vol 139. Ocean Drilling Program College Station, pp 447-465

Simoneit BRT (2018) Hydrothermal petroleum. In: Wilkes H (ed) Hydrocarbons Oils and Lipids: Diversity Origin Chemistry and Fate Handbook of Hydrocarbon and Lipid Microbiology Springer International Publishing AG part of Springer Nature. https://doi.org/10.1007/978-3-319-54529-5_16-2

Stasiuk LD (1997) The origin of pyrobitumens in Upper Devonian Laduc Formation gas reservoir Alberta Canada: an optical and EDS study of oil to gas transformation. Mar Pet Geol 14:915-929

Tarnocai CA, Hattori K, Cabri LJ (1997) "Invisible" gold in sulfides from Campbell mine Red lake greenstone belt Ontario: evidence for mineralization during the peak of metamorphism. Can Miner $35: 805-815$

Tissot BP, Welte DH (1984) Petroleum formation and occurrence, 2nd edn. Springer, Berlin, p 699

Trubnikov LM (1976) Geological map: M-44-G (Oskemen) of the geological map of Kazakh SSR scale: 1:500000 Regionalgeological organization of East Kazakhstan (in Russian)

Umarbekova ZT, Dyusembaeva KSh (2019) The characteristics and formation of black shale-hosted Bakyrchik-type gold mineralization. Appl Earth Sci 128(2):61-62. https://doi.org/10.1080/ 2572683820191607183

Umarbekova ZT, Dyusembaeva KSh, Kubashev KT (2017a) The Bakyrchik deposit and views on the formation of the mineral deposits in black shale beds. SGEM 2(422):23-30 (in Russian)

Umarbekova ZT, Seltmann R, Dyussembayeva KSh, Kokkuzova M (2017b) The gold ore deposit Bakyrchik and views on the formation of the mineral deposits in black shale strata. SGEM Albenia Bulgaria 17(11):1111-1118

Usmanova NF, Bragina VI, Zhizhaeva AM, Merkulova EN, Bondarenkoa GN (2017) Comparative analysis of sequential leaching procedures for dissociation of rare earth elements in gold-bearing material. J Min Sci 53(6):1124-1132

Vikent'ev IV, Moloshag VP, Yudovskaya MA (2006) Speciation of noble metals and conditions of their concentration in massive sulfide ores of the Urals. Geol Ore Deposits 48(2):77-107

Volkov AV, Sidorov AS (2017) Invisible gold. Vestnik Rossiiskoi Akademii Nauk 87(1):40-49

Waples DW (2002) The kinetics of in-reservoir oil destruction and gas formation: constraints from experimental and empirical data and from thermodynamics. Org Geochem 31:553-575

Weizhen T, Haiming L, Jinghui Zh, Yanzhu G (2017) Preparation characterization and the adsorption characteristics of lignin/silica nanocomposites from cellulosic ethanol residue. RSC Adv 7:41176-41181

Wong K, Zhou M, Terry W, O'Brien H, Lahaye Y, Jacky S (2017) Constraints of fluid inclusions and in-situ S-Pb isotopic compositions on the origin of the North Kostobe sediment-hosted gold deposit Eastern Kazakhstan. Ore Geol Rev 81:256-269

Wood SA (1996) The role of humic substances in the transport and fixation of metals of economic interest (Au Pt Pd U V). Ore Geol Rev 11:1-33

Wu X, Delbove F (1989) Hydrothermal synthesis of gold-bearing arsenopyrite. Econ Geol 84:2029-2032

Wu Zh, Xiaoming S, Huifang X, Hiromi K, Yan W, Chi W, Yingzhi D, Xiguang D, Miao Y (2016) Occurrences and distribution of "invisible" precious metals in sulfide deposits from the Edmond hydrothermal field Central Indian Ridge Ore Geol Rev 79: $105-132$

Yuguang H, Yaqi L, Sheng H, Yukun LZF, Yingrui S (2017) Distribution and thermal maturity of devonian carbonate reservoir solid bitumen in Desheng Area of Guizhong depression South China. Hindawi Geofluids 2017:1-15

Zairi NM, Gluhov AP, YaV V (1987) Isotopic-geochemical model of gold deposits. Soviet Geol 6:101-108

Zhautikov TM, Maulenov AM (1985) Types of stratiform gold of Kazakhstan mineralization. Izv Akad Nauk Kazakh SSR Ser Geol 5:81-87 (in Russian)

Zhu Y, Fang A, Juanjuan T (2011) Geochemistry of hydrothermal gold deposits: a review. Geosci Front 2(3):367-374 